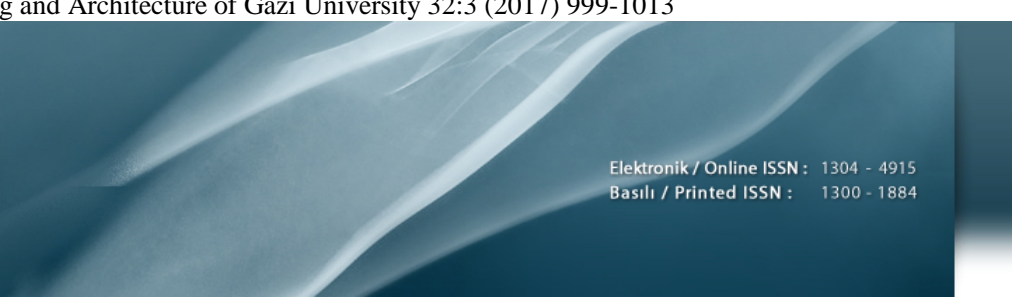

\title{
Manyetik parçacık görüntüleme için sinyal-gürültü oranını eniyileyen görüntü geriçatım tekniği
}

\author{
Ecem Bozkurt ${ }^{1,2}$ (D), Emine Ülkü Sarıtaş ${ }^{1,2,3^{*}}$ \\ ${ }^{1}$ Bilkent Üniversitesi, Elektrik ve Elektronik Mühendisliği Bölümü, 06800, Bilkent, Ankara, Türkiye \\ ${ }^{2}$ Bilkent Üniversitesi, Ulusal Manyetik Rezonans Araștırma Merkezi, 06800, Bilkent, Ankara, Türkiye \\ ${ }^{3}$ Bilkent Üniversitesi, Sinirbilim Programı, Sabuncu Beyin Araştırmaları Merkezi, 06800, Bilkent, Ankara, Türkiye
}

Ö N E Ç I K A N L A R

- $\quad$ Süperparamanyetik nanoparçacıkların uzamsal dağılımının görüntülenmesi

- Kısmi görüş alanlarının tarama hızının karesi ile ağırlıklandırılmasına dayalı görüntü geriçatımı

- Sinyal-gürültü oranını eniyileyen ve görüntü kalitesini artıran görüntü geriçatım tekniği

Makale Bilgileri

Geliş: 29.07.2017

Kabul: 08.09.2017

DOI:

10.17341/gazimmfd.337864

Anahtar Kelimeler:

Manyetik parçacık

görüntüleme,

görüntü geriçatımı,

sinyal-gürültü oranı,

süperparamanyetik demir

oksit nanoparçacıkları,

anjiyografi

\section{ÖZET}

Manyetik parçacık görüntüleme (MPG), süperparamanyetik demir oksit nanoparçacıklarının uzamsal dağılımını görüntüleyen yeni bir biyomedikal görüntüleme tekniğidir. MPG'de nanoparçacıkların zamana göre değişen mıknatıslanma tepkisine neden olan eksitasyon manyetik alanının genliği, sinir uyarım güvenlik sınırları tarafından kısıtlanmaktadır. Bu nedenle görüntülenmek istenen bölge ufak parçalara bölünür ve birbiriyle örtüşen kısmi görüş alanları şeklinde taranır. Eksitasyon alanının alıcı bobinde oluşturduğu doğrudan besleme sinyalinin bastırılması sürecinde, nanoparçacıkların da eksitasyon frekansındaki sinyali kaybolur. Bu kaybın telafisi için, istenen görüntünün sürekliliği ve pozitifliği kullanılarak örtüşen kısmi görüş alanları birleştirilir. Bu çalışmada sinyal-gürültü oranını (SGO) eniyileyecek şekilde kısmi görüş alanlarının birleştirilmesini sağlayan bir görüntü geriçatım tekniği sunulmaktadır. Buna göre her bir kısmi görüş alanı, konuma bağlı olarak değişen tarama hızının karesi ile ağırlıklandırılmalıdır. Farklı örtüşme yüzdeleri ve SGO değerlerinde gerçekleştirilen kapsamlı benzetimler ile önerilen yöntemin standart MPG geriçatım tekniklerinin neden olduğu dikey çizgi artefaktlarından kurtulmayı sağladığı ve görüntü kalitesini artırdı̆̆ gösterilmiştir.

\section{Signal-to-noise ratio optimized image reconstruction technique for magnetic particle imaging}

\section{H I G H L I G H T S}

- Imaging of the spatial distribution of superparamagnetic nanoparticles

- An image reconstruction based on weighting the partial fields-of-view with the squared scanning speed

- An image reconstruction technique that optimizes the signal-to-noise ratio and improves image quality

\section{Article Info}

Received: 29.07.2017

Accepted: 08.09.2017

\section{DOI:}

10.17341/gazimmfd.337864

Keywords:

Magnetic particle imaging, image reconstruction, signal-to-noise ratio, superparamagnetic iron oxide nanoparticles, angiography

\section{ABSTRACT}

Magnetic particle imaging (MPI) is a new biomedical imaging modality that images the spatial distribution of superpamagnetic iron oxide nanoparticles. In MPI, the amplitude of the excitation magnetic field that causes the time-varying magnetization response of the nanoparticles is restricted by the nerve stimulation safety limits. Hence, the region to be imaged is divided into small sections and scanned as overlapping partial fields-of-view. The nanoparticle signal at the excitation frequency is lost during the filtering process of the direct feedthrough signal induced on the receive coil due to the excitation field. To recover this loss, the overlapping partial fields-of-view are merged via utilizing the continuity and positivity of the desired image. In this work, an image reconstruction technique that merges the partial fields-of-view while optimizing the signal-to-noise ratio is proposed. Accordingly, each partial field-of-view must be weighted by the square of the position-dependent scanning speed. Via extensive simulations at various overlap percentages and signalto-noise ratios, this work demonstrates that the proposed method overcomes the vertical line artifacts caused by the standard MPI reconstruction techniques and improves image quality. 


\section{GİRIŞ̧ (INTRODUCTION)}

Manyetik parçacık görüntüleme (MPG) ilk olarak 2005 yılında yayınlanan yeni bir biyomedikal görüntüleme tekniğidir [1]. MPG'de süperparamanyetik demir oksit nanoparçacıklarının manyetik alana verdiği doğrusal olmayan tepkiden faydalanılarak, bu nanoparçacıkların uzamsal dağılımının görüntüsü oluşturulur. İnsan vücudundaki dokular benzer bir tepki vermediği için, MPG'de dokudan hiç sinyal alınmaz. Bu nedenle MPG görüntüleri ideal kontrasta sahiptir [2, 3]. Bu yüksek kontrast özelliği anjiyografi (damar görüntüleme) [4, 5], kök hücre takibi [6, 7], kanser görüntüleme [8] gibi önemli uygulamalar için MPG'yi umut vaat eden bir görüntüleme tekniği yapmaktadır. Bunun yanı sıra, nanoparçacıklardan alınan sinyal hem nanoparçacığın kimyasal ve fiziksel yapısına, hem de içinde bulundukları ortamın akışmazlık ve sıcaklık gibi özelliklerine de bağlıdır. Farklı nanoparçacıkların sinyallerini veya aynı nanoparçacıkların farklı ortamlardaki sinyallerini ayırt ederek "renkli MPG" görüntüleme de yapılabilmektedir [9]. Buna ek olarak, farklı akışmazlığa sahip dokuların (örneğin sağlıklı dokuya karşın kanserli dokuların) renkli MPG ile ayırt edilmesi de mümkün olabilir [10]. Diğer tıbbi görüntüleme yöntemlerinde olduğu gibi, hem normal MPG görüntülerinde hem de renkli MPG görüntülerinde bölütleme yöntemleri kullanılarak sağlıklı ve hastalıklı dokular ayrıştırılabilir [11, 12].

MPG'de nanoparçacıklardan sinyal elde etmek için 10-150 $\mathrm{kHz}$ aralığında tek frekansta alternatif akıml (AC) manyetik alan uygulanmaktadır. Eksitasyon alanı olarak adlandırılan bu manyetik alanın genliği ne kadar büyükse, taranan görüş alanı da o kadar geniş olur. Ne var ki, biyomedikal görüntülemede kullanılan manyetik alanların genliği, manyetik alan kaynaklı sinir atımı [13] ve manyetik alan kaynaklı doku isınması [14] ile sınırlıdır. MPG'de kullanılan eksitasyon alanının frekansı görece düşük olduğundan, insanlar üzerindeki güvenlik sınırları sinir atımı eşiği tarafindan belirlenmektedir [15]. Uygulanan manyetik alanın frekansına [15], süresine [16] ve görev döngüsüne [17] bağlı olarak değişen bu güvenlik sınırları görüş alanını önemli ölçüde kısıtlar. Bu kısıtlama nedeniyle tüm görüş alanını tek bir seferde taramak yerine, daha ufak kısmi görüş alanlarına bölerek görüntülemek gerekmektedir. Bir diğer önemli konu ise, MPG'de eksitasyon alanının uygulanması ile sinyal alımının aynı anda gerçekleşmesi ve bu nedenle eksitasyon alanının alıcı bobinde doğrudan besleme sinyaline neden olmasıdır. Eğer filtrelenmezse bu sinyal nanoparçacıklardan gelen sinyalden milyon kat büyüktür. Eksitasyon manyetik alanı tek bir frekansta olduğu için, yalnızca o frekansı filtreleyen bir yüksek geçiren veya bant söndüren süzgeç uygulanması ile doğrudan besleme sinyalinden kurtulmak mümkündür. Bu süzgeç aynı zamanda nanoparçacıkların o frekanstaki sinyalini de yok eder ve bunun sonucu olarak her bir kısmi görüş alanı sabit (DC) değer kaybına uğrar [5]. Önceki çalışmalarda MPG görüntüsünün sürekliliği kullanılarak DC kayıplarının hesaplanması ve sonrasında kısmi görüş alanlarından gelen görüntülerin birleştirilmesi önerilmiştir [5].

$\mathrm{Bu}$ çalışmada MPG sinyalinde gürültü olması durumunda kısmi görüss alanlarının sinyal-gürültü oranını (SGO) eniyileyecek şekilde birleştirilmesini sağlayan yeni bir geriçatım yöntemi önerilmektedir. Bu geriçatımda her bir kısmi görüş alanından gelen görüntü, konuma göre değişen bir şekilde o andaki tarama hızının karesi ile ağırlıklandırılmaktadır. Önerilen yöntemin başarımı, kısmi görüş alanları arası farklı örtüşme değerlerinde, farklı SGO değerlerinde ve nanoparçacıkların idealden sapan relaksasyon tepkileri de göz önüne alınarak kapsamlı benzetimlerle incelenmiştir. Bu incelemelere göre önerilen geriçatım, standart MPG geriçatımlarına göre daha yüksek kalitede görüntüler üretmektedir. Bu sonuçlar MPG ile yüksek SGO ve görüntü kalitesi elde edilmesi açısından önem taşımaktadır.

\section{X-UZAYI MPG GERICCATIMI (X-SPACE MPI RECONSTRUCTION)}

MPG'de yaygın olarak kullanılan iki farklı görüntü geriçatım tekniği vardır: Matris evirme işlemine dayanan sistem fonksiyonu geriçatımı [1] ve sinyalin o anki tarama noktasına atanmasına dayalı x-uzayı geriçatımı [18]. Sistem fonksiyonu geriçatımı için öncelikle nanoparçacıkların MPG tarayıci içerisindeki her noktadaki tepkisini karakterize eden bir sistem matrisi verisi toplanması gerekmektedir. Bu kalibrasyon verisinin toplanması saatler (örneğin 12-24 saat) sürmektedir. Üstelik nanoparçacıkların tepkisi bulundukları ortamın özellikleri nedeniyle değișecek olursa, bu sistem matrisi geçersiz olmakta ve görüntü kalitesi ciddi seviyede bozulabilmektedir. X-uzayı geriçatımında ise nanoparçacıkların tepkisi hakkında herhangi bir varsayım yapılmaz ve bu teknik ön kalibrasyon verisi gerektirmez.

Bu bölümde ilk olarak MPG sistemine genel bir bakış ve tek boyutlu görüntüleme için x-uzayı geriçatımı anlatılmaktadır. Sistem fonksiyonu geriçatımı bu makalenin kapsamı dışında olduğu için bu konuya değinilmemiştir. X-uzayı geriçatımında üç boyutlu görüntüleme için matematiksel eşitlikler daha karmaşık olsa da, ana fikir ve temel geriçatım işlemleri tek boyutlu görüntüleme ile aynıdır [19].

\subsection{Bir Boyutlu MPG Sistemine Genel Bakış (Overview of One-Dimensional MPI System)}

MPG'deki sinyalin kaynağı, süperparamanyetik demir oksit nanoparçacıklarının uygulanan manyetik alana verdiği doğrusal olmayan tepkidir. Düşük şiddette manyetik alan uygulandığında nanoparçacık mıknatıslanması neredeyse doğrusal olarak değişirken, yüksek şiddette manyetik alan uygulandığında mıknatıslanma doyuma ulaşmaktadır. Bir nanoparçacık topluluğu için bu mıknatıslanma eğrisi Eş. 1 'de verilmiştir. $\mathrm{Bu}$ eğri Langevin fonksiyonu, $\mathcal{L}(\cdot)$, ile modellenmektedir [18]. 
$M(H)=m_{s} \rho \mathcal{L}\left(\frac{H}{H_{\text {sat }}}\right)=m_{s} \rho\left[\operatorname{coth}\left(\frac{H}{H_{\text {sat }}}\right)-\frac{1}{\left(\frac{H}{H_{\text {sat }}}\right)}\right]$

$\mathrm{Bu}$ eşitlikte $\rho$ nanoparçacık yoğunluğudur. Doygunluk manyetik momenti $\left(m_{s}\right)$ Eş. 2'de, nanoparçacıkları yarı doygunluğa ulaştırmak için uygulanması gereken manyetik alan $\left(H_{\text {sat }}\right)$ ise Eş. 3 'te verilmiştir.

$m_{s}=\frac{\pi d^{3} M_{S}}{6}$

$H_{\text {sat }}=\frac{k_{B} T}{\mu_{0} m_{s}}$

Burada $d$ nanoparçacıkların manyetik çekirdek çapı, $M_{S}$ doyum mıknatıslanması (magnetit nanoparçacıkları için 0,6 $\left.\mathrm{T} / \mu_{0}\right), k_{B}$ Boltzmann sabiti, $T$ mutlak sicaklık, $\mu_{0}$ vakum geçirgenliğidir. $\mathrm{Bu}$ eşitliklere göre nanoparçacık çap1 arttıkça nanoparçacıklar daha çabuk doyuma ulaşmaktadırlar. Şekil 1a'da $25 \mathrm{~nm}$ çapında magnetit demir oksit nanoparçacıklarının Langevin tepkisi verilmiştir.

MPG'de nanoparçacıkların uzamsal dağılım görüntüsünü elde edebilmek için, yalnızca ufak bir bölge etrafindaki nanoparçacıkların seçilmesi ve yalnızca bu nanoparçacıkların sinyal verebilir hale gelmesi hedeflenmektedir. Bu amaçla Şekil 1b'de gösterildiği gibi birbirine zit yönde manyetik alan yaratacak sekilde yerleştirilmiş iki adet sabit mıknatıs kullanılır. Böylece MPG tarayıcının merkezinde bir manyetik alansız bölge (MAB) yaratılır. Sabit miknatıslar tarafindan uygulanan statik manyetik alana "seçme alanı" denir. Bu alana ek bir alternatif manyetik alan uygulandığında yalnızca MAB içindeki nanoparçacıklar tepki verebilirken, MAB dışındaki nanoparçacıklar doyumda oldukları için tepkisiz kalırlar. Böylece uzayda tek nokta seçilerek yalnızca o noktadan sinyal alınması sağlanmış olur. Son olarak, görüntülenmek istenen hacimde MAB gezdirilir (doğrusal hareket robotları veya ek manyetik alanlar yardımiyla) ve her noktadan gelen sinyal kaydedilerek bir görüntüye dönüştürülür. Seçme alanının gradyanı (yani uzamsal türevi) ne kadar yüksekse, MPG görüntüsünün çözünürlüğü de o kadar yüksektir.

\section{2. $M P G$ 'de Bir Boyutlu Görüntü Geriçatımı \\ (One Dimensional Image Reconstruction in MPI)}

Tek boyutlu uzamsal nanoparçacık dağılımı için elde edilebilecek ideal MPG görüntüsü, $\hat{\rho}(x)$, Eş. 4'teki gibi ifade edilebilir [18].

$\hat{\rho}(x)=\rho(x) * h(x)$

Burada yıldız işareti evrişim işlemini belirtmektedir. $\rho(x)$ nanoparçacıkların uzamsal dağılım yoğunluğu, $h(x)$ ise görüntüleme sisteminin nokta dağılım fonksiyonudur (NDF). Şekil 1c'de gösterilen ve Eş. 5'te verilen bu NDF, nanoparçacıkların Langevin tepkisinin türevine eşittir [18].

$h(x)=\dot{\mathcal{L}}\left(\frac{G x}{H_{\text {sat }}}\right)=\frac{1}{\left(\frac{G x}{H_{\text {sat }}}\right)^{2}}-\frac{1}{\sinh ^{2}\left(\frac{G x}{H_{\text {sat }}}\right)}$

Burada $G$ seçme alanının x yönündeki gradyanıdır. MPG'de endüktif bobinler aracılığıyla alınan sinyal, toplam mıknatıslanmanın zamana göre türevi ile doğru orantılıdır. Toplam miknatislanma ise $\rho(x)$ ile $\mathcal{L}\left(G x / H_{\text {sat }}\right)$ fonksiyonlarının evrişimi ile doğru orantılıdır. Sinyalin matematiksel ifadesindeki zamana göre türev işlemi, NDF'nin Langevin tepkisinin türevine eşit olmasına neden olmaktadır (detaylar için bkz. [18]). Bu NDF'nin yarı-doruk genişliğine bakılarak MPG görüntüsünün uzamsal çözünürlüğü Eş. 6'daki gibi hesaplanabilir [18].

$\Delta x \approx \frac{4.16 H_{S a t}}{G}$

Buna göre yüksek çözünürlükte görüntü (yani küçük $\Delta x$ ) için düşük $H_{s a t}$ veya yüksek $G$ gerekmektedir. Bu iki durumda da nanoparçacıklar MAB'dan kısa bir mesafe uzaklıkta bile doyuma ulaşırlar ve böylece "etkin” MAB boyutu küçülmüş olur. Şekil 1c'de $3 \mathrm{~T} / \mathrm{m} / \mu_{0}$ gradyan alan ve $25 \mathrm{~nm}$ çapında

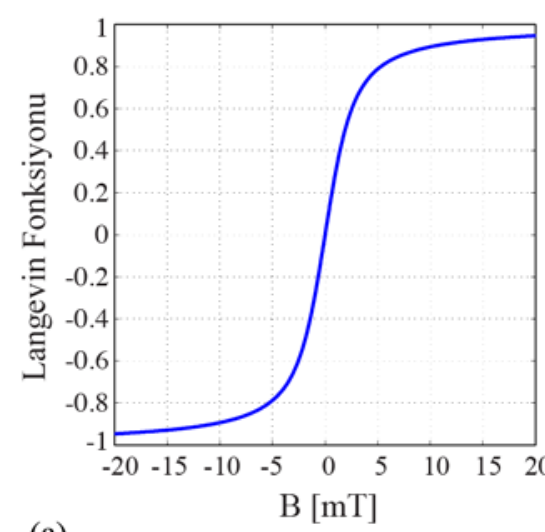

(a)

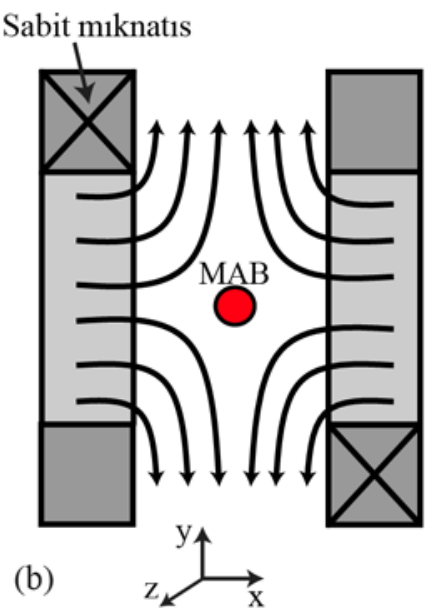

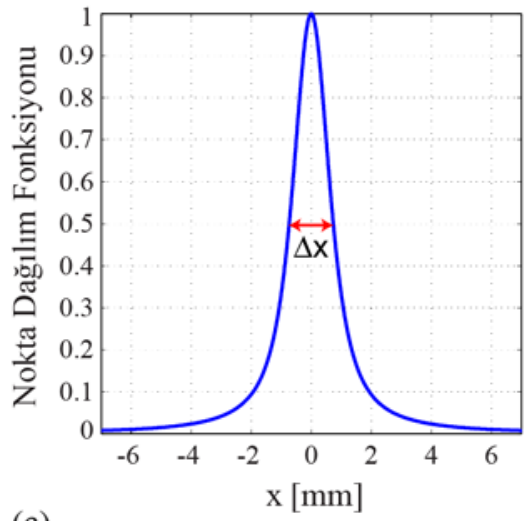

(c)

Şekil 1. Manyetik parçacık görüntülemenin (MPG) temel prensipleri (a) Süperparamanyetik demir oksit nanoparçacıkların Langevin tepkisi (b) MPG tarayıcı şematiği (c) MPG'de nokta dağılım fonksiyonu (Principles of magnetic particle imaging (MPI)

(a) Langevin response of superparamagnetic nanoparticles (b) Schematic of an MPI scanner (c) Point spread function in MPI) 
magnetit parçacıkları için NDF verilmiştir. Bu durum için MPG çözünürlüğü $\Delta x \approx 1,47 \mathrm{~mm}$ olarak hesaplanabilir. Görüntüleme sırasında seçme alanına ek olarak bir alternatif manyetik alan uygulanır. "Eksitasyon alanı" veya "sürme alanı" olarak isimlendirilen bu manyetik alan tipik olarak $f_{0}$ $=25 \mathrm{kHz}$ civarında sabit genlikli, uzamsal olarak homojen bir manyetik alandır. İdeal bir seçme alanı $\left(H_{s}\right)$ Eş. 7'deki gibi ve eksitasyon alanı $\left(H_{e}\right)$ Eş. 8'deki gibi ifade edilir [5].

$H_{S}(x)=-G x$

$H_{e}(t)=H_{0} \cos \left(2 \pi f_{0} t\right)$

Burada seçme alanının negatif gradyanlı olarak tanımlanması sonraki aşamalarda matematiksel kolaylık sağlaması içindir. $H_{s}(x)+H_{e}(t)=0$ eşitliğini çözerek MAB'ın anlık konumu (yani o an için uzayda taranan nokta), $x_{s}$, Eş. 9'daki gibi hesaplanabilir [5].

$x_{s}(t)=\frac{H_{0}}{G} \cos \left(2 \pi f_{0} t\right)=\frac{W}{2} \cos \left(2 \pi f_{0} t\right)$

$\mathrm{Bu}$ eşitliğe göre $\mathrm{x}$ yönünde $\pm W / 2$ arasındaki bölge ileri/geri taranmaktadır ve görüş alanı $W=2 H_{0} / G$ genişliğindedir. Tarama sırasında alıcı endüktif bobinler aracılığıyla kaydedilen sinyal ise Eş. 10'daki gibi ifade edilir [18].

$s_{\text {ideal }}(t)=\gamma \hat{\rho}\left(x_{s}(t)\right) \dot{x}_{s}(t)$

Burada $\gamma$ endüktif bobinin hassasiyetine, nanoparçacıkların manyetik özelliklerine ve MPG tarayıcının seçme alanının gradyanına bağlı bir sabittir [18]. $\dot{x}_{s}(t)$ ise MAB'ın anlık tarama hızıdır. Sinyal endüktif olarak alındığı için tarama hızı arttıkça nanoparçacık mıknatıslanmasının $d M / d t$ değeri artmakta ve bu nedenle sinyal seviyesi de artmaktadır. Anlık tarama hızı bilindiği için, bu sinyalden MPG görüntüsü Eş. 11 'deki gibi oluşturulabilir.

$\operatorname{IMG}\left(x_{S}(t)\right)=\hat{\rho}\left(x_{S}(t)\right)=\frac{s_{\text {ideal }}(t)}{\gamma \dot{x}_{s}(t)}$

Kısaca, kaydedilen sinyal tarama hızına bölünür ve o andaki MAB konumu olan $x_{s}(t)$ noktasina atanır.

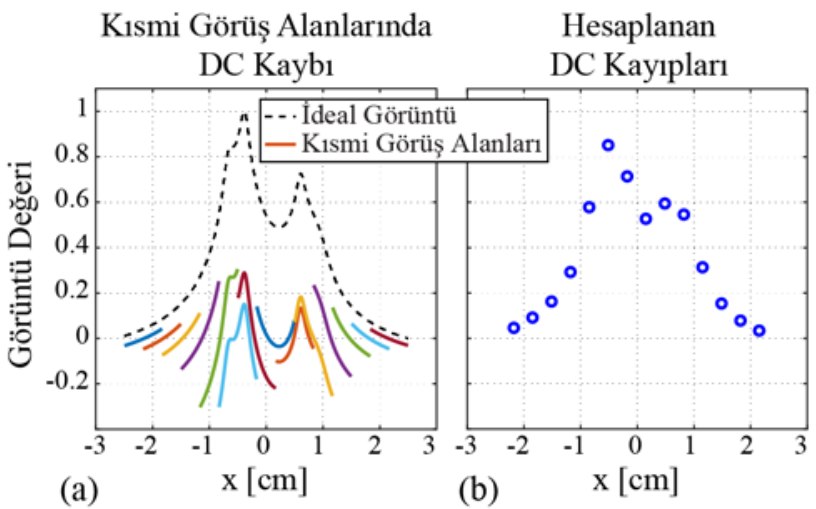

MPG'de kullanılan eksitasyon alanının genliği, $H_{0}$, manyetik alanların insanlar üzerindeki güvenlik limitleri ile sınırlıdır [15]. Bu durum görüş alanı genişliğini kısıtlamaktadır. Bu nedenle birbiriyle örtüşen kısmi görüş alanları taranır ve bu kısmi görüntülerin birleştirilmesi ile hedeflenen daha geniş görüş alanı taranmış olur. $\mathrm{Bu}$ amaçla odaklanma alanı $\left(H_{\text {odak }}\right)$ adı verilen, eksitasyon alanına göre daha düşük frekansta çalışan (tipik olarak $100 \mathrm{~Hz}$ ve altı [20]) ve uzamsal olarak homojen bir manyetik alan uygulanır. $H_{s}(x)+$ $H_{\text {odak }}(t)+H_{e}(t)=0$ eşitliğini çözünce MAB'ın anlık konumu Eş. 12'deki gibi hesaplanabilir.

$x_{S}(t)=\frac{H_{\text {odak }}(t)}{G}+\frac{W}{2} \cos \left(2 \pi f_{0} t\right)$

Böylece odaklanma alanı ile MAB'ın ortalama konumu uzayda geniş bir görüş alanı içerisinde gezdirilirken, eksitasyon alanı ile kısmi görüş alanlarının hızlı taraması gerçekleştirilmiş olur.

\subsection{MPG'de Doğrudan Besleme Sorunu ve DC Kurtarım Geriçatımı \\ (Direct Feedthrough Problem in MPI and DC Recovery Reconstruction)}

MPG'de nanoparçacıklara uygulanan eksitasyon alanı tek bir frekanstadır; ama nanoparçacıkların doğrusal olmayan tepkisi hem bu temel frekansta hem de tüm yüksek harmoniklerinde sinyal oluşturur. Sinyal alıcı bobin ve eksitasyon bobini arasındaki karşılıklı endüktanstan dolayı temel harmonik frekansında nanoparçacıkların sinyalinin çok üzerinde bir doğrudan besleme oluşur. Bu nedenle temel frekansın tamamen filtrelenmesi için yüksek geçiren veya bant söndüren süzgeç uygulanır. Bu süzgeç sonrası oluşan görüntü normal görüntüye göre sabit bir değer kaybına (DC kaybı) uğramış olur. Bu durum Eş. 13'teki gibi ifade edilebilir [5].

$I M G_{i}{ }^{\prime}(x)=I M G_{i}(x)-\alpha_{i}$

Burada $I M G_{i}$ her bir kısmi görüş alanının ideal görüntüsü, $\alpha_{i}$ ise her bir kısmi görüş alanının maruz kaldığı DC değer kaybıdır. Şekil 2a'da gösterildiği gibi, her bir kısmi görüş alanı farklı bir DC kaybına uğrar. MPG görüntüsü sürekli

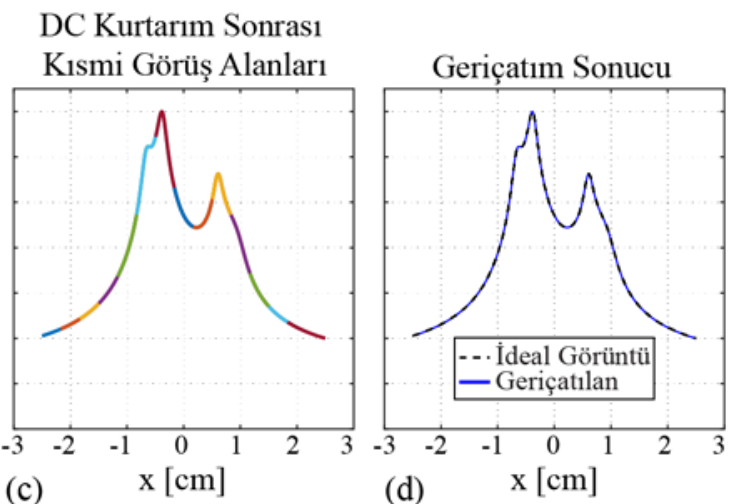

Şekil 2. (a) MPG'de doğrudan besleme sorunu nedeniyle DC kaybına uğramış kısmi görüş alanları (b) Hesaplanan DC kayıpları (c) DC kurtarım sonrası kısmi görüş alanları (d) Geriçatılan görüntü ( (a) Partial fields-of-view after DC loss due to the direct feedthrough problem in MPI (b) Calculated DC losses (c) Partial fields-of-view after DC recovery (d) Reconstructed image) 
olduğu ve ani sıçramalar gösteremeyeceği için, DC kayıpları kısmi görüş alanlarının örtüşen kısımları kullanılarak hesaplanır (bkz. Şekil 2b). Şekil 2c'de gösterilen DC değerleri kurtarılmış kısmi görüş alanları birleştirilir ve son görüntü elde edilmiş olur. Şekil 2d'de gösterildiği gibi, sinyalde hiç gürültü olmaması durumunda bu geriçatım ideal görüntüyü vermektedir [5]. Eş. 13 odaklanma alanının zamana göre parçalı sabit olduğu durum için türetilmiş olsa da [5], odaklanma alanı gerçekçi değerlerde tutulduğu sürece geçerlidir [21].

\section{TEORİK VE BENZETIMSEL METOTLAR (THEORETICAL AND SIMULATION METHODS)}

Bu çalışmada, MPG sinyalinde gürültü olması durumunda son görüntünün $\mathrm{SGO}$ değerini eniyileyen bir geriçatım yöntemi önermekteyiz. Buna göre, DC değer kayıpları hesaplandıktan sonra kısmi görüş alanları birleştirilirken, her bir kısmi görüş alanından gelen görüntü konuma göre değişen kısmi SGO değerinin karesi ile ağırlıklandırılmalıdır. Bu yöntemin matematiksel çıkarımı ve nicel analizi bu bölümde sunulmuştur.

\subsection{Klsmi Görüş Alanlarında SGO (SNR in Partial Fields-of-View)}

Eş. 11'den başlayarak, MPG sinyalinin gürültülü olması durumunda her bir kısmi görüş alanı için SGO seviyesi kolayca hesaplanabilir. İndeksi $i$ olan kısmi görüş alanından gelen görüntü, Eş. 14'teki gibi ifade edilebilir:

$I M G_{i}\left(x_{s}\right)=\frac{s_{\text {ideal }}+n_{i}}{\gamma \dot{x}_{s}}=\hat{\rho}\left(x_{s}\right)+\frac{n_{i}}{\gamma \dot{x}_{s, i}}$

Burada $n_{i}$ toplanır gürültüyü ifade etmektedir (ideal olarak beyaz Gauss gürültüsü). Her bir kısmi görüş alanı için gürültünün birbirinden bağımsız ve aynı dağılıma sahip olduğunu varsayarsak, sabit bir $x_{s}$ konumundaki SGO, MAB'ın o konumdaki mutlak hızı olan $\left|\dot{x}_{s, i}\right|$ ile doğru orantılıdır. Bir diğer deyişle, MAB hızlı hareket ederken nanoparçacıkların mıknatıslanması da hızla değiştiği için, mıknatıslanmanın zamana karşı türevine denk gelen sinyal de daha yüksek seviyede olmaktadır. Sinyaldeki gürültü seviyesi aynı kaldığı için, MAB hızlı hareket ederken SGO da yüksek olmaktadır.

SGO'yu hiz yerine konum cinsinden ifade etmek daha yararlıdır. Bunun için öncelikle Eş. 9'u kısmi görüş alanlarına uyarlayınca, Eş. 15'teki gibi ifade elde edilir.

$x_{s}=x_{i}+\frac{W}{2} \cos \left(2 \pi f_{0} t\right)$

Burada $x_{i}$, indeksi $i$ olan kısmi görüş alanının merkezidir. Eş. 15 ile Eş. 12 karşılaştırılınca, $x_{i}=H_{\text {odak }} / G$ olarak hesaplanabilir. $\mathrm{Bu}$ eşitlikten başlayarak MAB'ın hızı, konumu cinsinden Eş. 16'daki gibi ifade edilebilir.

$$
\begin{aligned}
& \dot{x}_{s, i}=-W \pi f_{0} \sin \left(2 \pi f_{0} t\right)=-W \pi f_{0} \sin \left(\operatorname{acos}\left(\frac{2\left(x_{s}-x_{i}\right)}{W}\right)\right)= \\
& -W \pi f_{0} \sqrt{1-\left(\frac{2\left(x_{s}-x_{i}\right)}{W}\right)^{2}}
\end{aligned}
$$

Böylece, $x_{s}$ konumundaki normalize edilmiş SGO (NSGO) doğrudan o konum cinsinden Eş. 17'deki gibi ifade edilebilir.

$N S G O_{i}\left(x_{s}\right)=\sqrt{1-\left(\frac{2\left(x_{s}-x_{i}\right)}{W}\right)^{2}}$, ĕger $\left|x_{s}-x_{i}\right| \leq \frac{W}{2}$

Burada SGO'nun görece değişimini hesaplamayı hedeflediğimiz için, baştaki sabitler yok sayılarak normalize edilmiş (yani en yüksek değeri 1 olan) bir metrik hesaplanmıştır. Şekil 3a'da $20 \mathrm{~cm}$ genişliğindeki görüş alanının \%20 örtüşen 12 kısmi görüş alanı ile görüntülendiği durum ve bu durumda her bir kısmi görüş alanının Eş. 17 ile hesaplanan normalize SGO değeri verilmiştir. Buna göre, kısmi görüş alanlarının ortasında en yüksek olan SGO, her bir kısmi görüş alanının kenarlarında sıfıra düşmektedir.

\subsection{Kısmi Görüş Alanlarının Doğrudan Birleştirilmesi (Direct Stitching of Partial Fields-of-View)}

Kısmi görüş alanlarının DC düzeltimi sonrası doğrudan ortalamalarının alınarak birleştirilmesi durumunda, $x_{s}$ konumundaki görüntü Eş. 18'deki gibi ifade edilebilir.

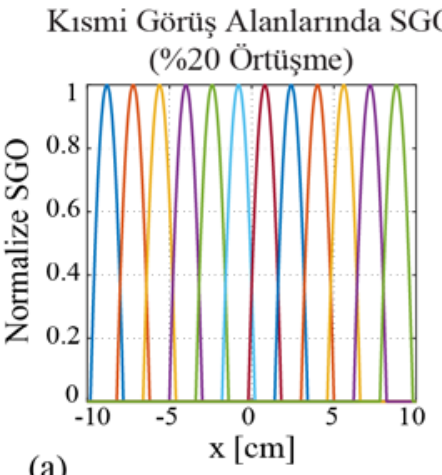

(a)

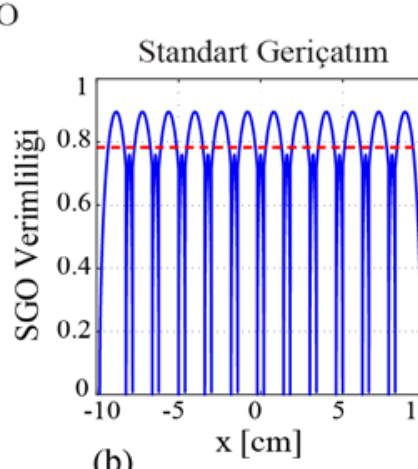

(b)
Kesme Sonras 1 Standart Geriçatım

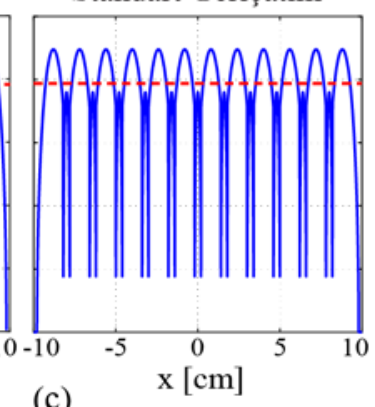

(c)

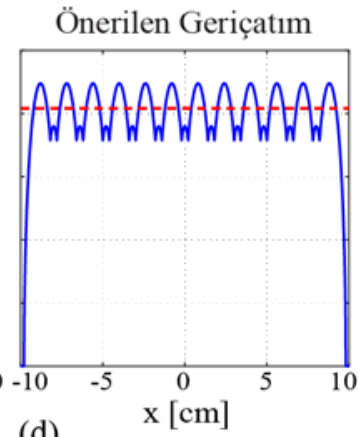

(d)

Şekil 3. (a) \%20 örtüşme ile görüntüleme durumunda kısmi görüş alanları için normalize SGO (b) Standart geriçatım (c) kesme sonrası standart geriçatım ve (d) önerilen geriçatım için SGO verimliliği

( (a) Normalized SNR for partial fields-of-view in the case of imaging with $20 \%$ overlap SNR efficiency for (b) the standard reconstruction (c) the standard reconstruction after cutting and (d) the proposed reconstruction) 
$\operatorname{IMG}\left(x_{s}\right)=\frac{1}{K} \sum_{i=1}^{K} I M G_{i}\left(x_{s}\right)=\hat{\rho}\left(x_{s}\right)+\frac{1}{K} \sum_{i=1}^{K} \frac{n_{i}}{\gamma \dot{x}_{s, i}}$

Burada $K, x_{s}$ konumundan geçen kısmi görüş alanı sayısıdır. Gürültünün her bir kısmi görüş alanı için birbirinden bağımsız ve $\mathcal{N}\left(0, \sigma^{2}\right)$ dağılıma sahip olduğunu varsayarsak, bu standart geriçatım ile birleştirilmiş görüntüde $x_{s}$ konumundaki gürültünün standart sapması Eş. 19'daki gibi ifade edilebilir.

$\sigma^{\prime}\left(x_{s}\right)=\frac{1}{K} \sqrt{\sum_{i=1}^{K} \frac{\sigma^{2}}{\gamma^{2} \dot{x}_{s, i}{ }^{2}}}$

Bu eşitliği ve hız ile SGO arasındaki bağıntıyı kullanarak, $x_{s}$ konumundaki normalize SGO Eş. 20'deki gibi yazılabilir.

$$
\operatorname{NSGO}\left(x_{s}\right)=\frac{K}{\sqrt{\sum_{i=1}^{K} \frac{1}{\operatorname{NSGO}_{i}^{2}\left(x_{S}\right)}}}
$$

Görüntülemede bir konumdaki mutlak SGO’dan daha önemli olan, uygulanan yöntemin "SGO verimliliğii"dir. Aynı görüntü tekrar tekrar alınarak SGO kolayca artırılabilir, ama buna karşılık olarak görüntü süresi de uzayacaktır. Örneğin, aynı kısmi görüş alanı $K$ kere görüntülenip ortalaması alınsa, SGO değeri $\sqrt{K}$ ile doğru orantılı olarak artar. $\mathrm{Bu}$ nedenle SGO verimliliği (VSGO), normalize SGO'nun $\sqrt{K}$ ile bölünmüş hali olarak Eş. 21'deki gibi tanımlanmaktadır.

$\operatorname{VSGO}\left(x_{S}\right)=\frac{\operatorname{NSGO}\left(x_{S}\right)}{\sqrt{K}}$

Eş. 20 ve Eş. 21 incelenecek olursa, birleştirilen kısmi görüş alanlarının her birinde normalize SGO değerinin 1 olması durumunda, elde edilen SGO verimliliği de 1 olmaktadır. Bu, olabilecek en yüksek verimlilik değeridir. Şekil 3b'de ise Şekil 3a'da gösterilen \%20 örtüşme durumundaki kısmi görüş alanlarının doğrudan birleştirilmesi durumunda elde edilen SGO verimliliği gösterilmiştir. Her kısmi görüş alanının iki kenarındaki SGO sıfıra düştüğü için, standart geriçatım durumunda tüm görüş alanı içerisindeki pek çok konumda SGO verimliliği oldukça düşmektedir. Görüş alanı içindeki maksimum SGO verimliliği 0,89, minimum SGO verimliliği sıfırdır. Şekil 3b'deki kırmızı kesikli çizgi, tüm görüş alanı üzerindeki ortalama SGO verimliliğini 0,78 olarak göstermektedir.

Standart geriçatımda kısmi görüş alanlarının iki ucunda SGO'nun sıfıra düşmesi, tüm görüntüyü etkiler hale gelmektedir. Standart geriçatımı iyileştirmek ve gürültüye karşı daha gürbüz hale getirmek için kısmi görüş alanlarının yalnızca ortadaki \%95'lik kısmının tutulması, ve SGO'su düşük olan uçların kesilmesi önerilmiştir [5]. Bu kesme işlemi sonrasında yine doğrudan birleştirme gerçekleştirildiği için yukarıdaki eşitlikler hala geçerlidir (her bir $I M G_{i}$ yerine kesik hallerinin kullanılması şartı ile). Şekil 3c'de kesme sonrası standart geriçatım yöntemi ile elde edilen SGO verimliliği gösterilmiştir. Görüş alanı içindeki maksimum SGO verimliliği 0,89, minimum SGO verimliliğ
0,18, ortalama SGO verimliliği ise $0,79^{\prime}$ dur (kırmızı kesikli çizgi). $\mathrm{Bu}$ yöntemle $\mathrm{SGO}$ verimliliğinin sıfıra düşmesi engellenmiş olsa da, hala pek çok konumda SGO verimliliği oldukça düşük değerlerde kalmaktadır.

\subsection{MPG için SGO Eniyileyen Görüntü Geriçatımı (SNR Maximizing Image Reconstruction for MPI)}

$\mathrm{Bu}$ çalışmada, son görüntünün SGO seviyesini eniyilemek için, her bir kısmi görüş alanından gelen görüntünün SGO seviyesine göre ağırlıklandırılmasına dayalı bir yöntem önerilmektedir. Son SGO seviyesini eniyileyen ağırlıklandırmayı bulmak için problem Eş. 22'deki gibi ifade edilebilir.

$\operatorname{IMG}\left(x_{s}\right)=\frac{1}{\sum_{i=1}^{K} c_{i}} \sum_{i=1}^{K} c_{i} \cdot I M G_{i}\left(x_{s}\right) \hat{\rho}_{\text {ideal }}\left(x_{s}\right)+\frac{1}{\sum_{i=1}^{K} c_{i}}$

$\sum_{i=1}^{K} c_{i} \cdot \frac{n_{i}}{\gamma \dot{x}_{s, i}}$

Burada $c_{i}$, indeksi $i$ olan kısmi görüş alanına verilen ağırlıktır. Bölüm 3.2' de olduğu gibi, birbirinden bağımsız ve $\mathcal{N}\left(0, \sigma^{2}\right)$ dağılıma sahip gürültü varsayarsak, birleştirilmiş görüntüdeki gürültü seviyesi Eş. 23'teki gibi yazılabilir.

$\sigma^{\prime}\left(x_{s}\right)=\frac{1}{\sum_{i=1}^{K} c_{i}} \sqrt{\sum_{i=1}^{K} c_{i}^{2} \cdot \frac{\sigma^{2}}{\gamma^{2} \dot{x}_{s, i}{ }^{2}}}$

SGO seviyesini eniyilemek için $\sigma^{\prime}$ değerini en aza indirmek gerekmektedir. Bunu sağlayacak ağırlıklandırmayı hesaplamak için Eş. 24'te gösterildiği gibi $\sigma^{\prime}$ değerinin $c_{j}$ 'ye göre kısmi türevini sıfırlayan $c_{j}$ değeri bulunmalıdır.

$\frac{\partial \sigma^{\prime}}{\partial c_{j}}=0$

$-\frac{1}{\left(\sum_{i=1}^{K} c_{i}\right)^{2}} \sqrt{\sum_{i=1}^{K} c_{i}^{2} \cdot \frac{\sigma^{2}}{\gamma^{2} \dot{x}_{s, i}{ }^{2}}}+\frac{1}{\sum_{i=1}^{K} c_{i}} \frac{1}{2}\left(\sum_{i=1}^{K} c_{i}^{2} \cdot \frac{\sigma^{2}}{\gamma^{2} \dot{x}_{s, i}{ }^{2}}\right)^{-\frac{1}{2}}$

$2 c_{j} \frac{\sigma^{2}}{\gamma^{2} \dot{x}_{s, j}^{2}}=0$

$c_{j} \frac{1}{\dot{x}_{s, j}^{2}} \sum_{i=1}^{K} c_{i}=\sum_{i=1}^{K} \frac{c_{i}^{2}}{\dot{x}_{s, i}^{2}}$

$\mathrm{Bu}$ eşitliğin tüm $j$ indeksleri için geçerli olmasını sağlayan çözüm Eş. 25 'te verilmiştir.

$c_{j}=a \dot{x}_{s, j}^{2}$

Burada $a$, herhangi bir sabittir. Buna göre her bir kısmi görüş alanı, pozisyona bağlı tarama hızının karesi ile doğru orantılı bir şekilde ağırlıklandırılmalıdır. Bu sonucu Eş. 16 ve Eş. 17 ile karşılaştırırsak (ifadeyi sadeleştirecek bir $a$ değeri için) sonuç Eş. 26'daki gibi yazılabilir.

$c_{i}\left(x_{s}\right)=N S G O_{i}{ }^{2}\left(x_{s}\right)=1-\left(\frac{2\left(x_{s}-x_{i}\right)}{W}\right)^{2}$ 
Yani, her bir kısmi görüş alanı, pozisyona bağlı olarak SGO değerinin karesi ile ağırlıklandırılmalıdır. Bu ağırlıklandırma kullanılarak kısmi görüş alanları birleştirildiğinde elde edilen NSGO değeri Eş. 27'deki gibi hesaplanabilir.

$\operatorname{NSGO}\left(x_{s}\right)=\sqrt{\sum_{i=1}^{K} \operatorname{NSGO}_{i}^{2}\left(x_{s}\right)}$

SGO verimliliği hesabı için Eş. 21 hala geçerlidir. Şekil $3 c$ 'de \%20 örtüşme durumundaki kısmi görüş alanlarının önerilen bu yöntem ile ağırlıklandırılması sonucu elde edilen SGO verimliliği gösterilmiştir. Standart geriçatım yöntemlerinin aksine, önerilen yöntem ile SGO verimliliği tüm görüş alanında yüksek seviyelerdedir. Görüş alanı içerisindeki maksimum SGO verimliliği 0,89, minimum SGO verimliliği 0,72 'dir. Ortalama SGO verimliliği ise 0,82'dir (kırmızı kesikli çizgi). Burada minimum değer hesaplanırken, SGO verimliliğinin görüş alanının ortalarındaki denge değerleri kullanılmış, görüş alanının kenarlarında kalan kısımlar göz ardı edilmiştir. Görüş alanının kenarlarında yalnızca bir kısmi görüş alanı mevcut olduğu için SGO verimliliğinin iki kenarda sıfıra düşmesi kaçınılmazdır.

\subsection{SGO Verimliliği ve Dalgalanma Faktörü (SNR Efficiency and Ripple Factor)}

Şekil 3'te \%20 örtüşme için gösterilen benzetimler \%1-\%99 arası örtüşme değerleri için tekrarlanmış ve elde edilen sonuçlar Şekil 4'te verilmiştir. Şekil 4a'da standart geriçatım (yani Bölüm 3.2'de anlatılan doğrudan birleştirme yöntemi) için farklı örtüşme değerlerinde ortalama, maksimum ve minimum SGO verimliliği gösterilmiştir. Tüm örtüşme değerlerinde minimum SGO verimliliği sıfira düşmekte ve örtüşme değeri arttıkça maksimum değer de sıfira yakınsamaktadır. Bunun sebebi doğrudan birleştirme yönteminde SGO'su sıfir olan verinin, tüm birleştirme sonucunun SGO'sunu da sıfıra zorlamasıdır. Şekil 4b'de kesme sonrası standart geriçatım (yani kısmi görüş alanlarının yalnızca ortadaki \%95'lik kısmının kullanılması) için sonuçlar gösterilmiştir. Kesme işlemi minimum SGO verimliliğinin sıfıra inmesini engellese de, örtüşme yüzdesi $\% 88$ 'den azken minimum SGO verimliliği oldukça düşük bir değer olan 0,3'ün altında kalmaktadır. Buna ek olarak, bu yöntem ortalama SGO verimliliğinin artan örtüşme yüzdelerinde düşmesine engel olamamaktadır. Şekil 4c'de ise önerilen yöntem için farklı örtüşme değerlerinde ortalama, maksimum ve minimum SGO verimliliği gösterilmiştir. Açıkça görüldüğü gibi, önerilen yöntemde \%20 üzerinde örtüşme değerleri için ortalama SGO verimliliği sabit kalmaktadır. Ayrıca, artan örtüşme değerleri için maksimum ve minimum SGO verimliliği arasındaki fark gittikçe kapanmaktadır.

Yüksek SGO verimliliği elde edilmesine ek olarak, tüm görüş alanı üzerinde eşit verimlilikte SGO elde edilmesi de görüntü kalitesi açısından önem taşımaktadır. MPG'de SGO'nun tarama hızına bağlı değişimi nedeniyle, SGO konuma göre değişmektedir. Şekil 4a-c'de gösterildiği gibi, minimum ve maksimum SGO verimliliği arasında büyük farklar oluşabilmektedir. $\mathrm{Bu}$ farklılıkları sayısal olarak değerlendirebilmek için Eş. 28'de verilen dalgalanma faktörünü $(D F)$ öneriyoruz.

$D F=\frac{\max (V S G O)-\min (V S G O)}{\operatorname{ort}(V S G O)}$

Çokça kullanıldığı üzere dalgalanma faktörü, devre teorisinde doğrultucu devrelerin başarım seviyesini belirlemede kullanılan bir ölçüttür. Doğru akım kaynaklarından çıkan voltaj veya akım değerinin ne derece sabit değerde olduğunu ölçmek için kullanılır. Eş. 28'deki ölçütte maksimum ve minimum SGO verimliliği arasındaki farkın, ortalama SGO verimliliğine oranına bakılmaktadır. İdeal durumda dalgalanma faktörü sıfır olmalıdır. Şekil 4d'de standart geriçatım, kesme sonrası standart geriçatım ve önerilen geriçatım için farklı örtüşme yüzdelerinde dalgalanma faktörü gösterilmiştir. Hem standart geriçatımda hem de kesme sonrası standart geriçatımda dalgalanma faktörü çok yüksek seviyelerdedir. Standart geriçatım için
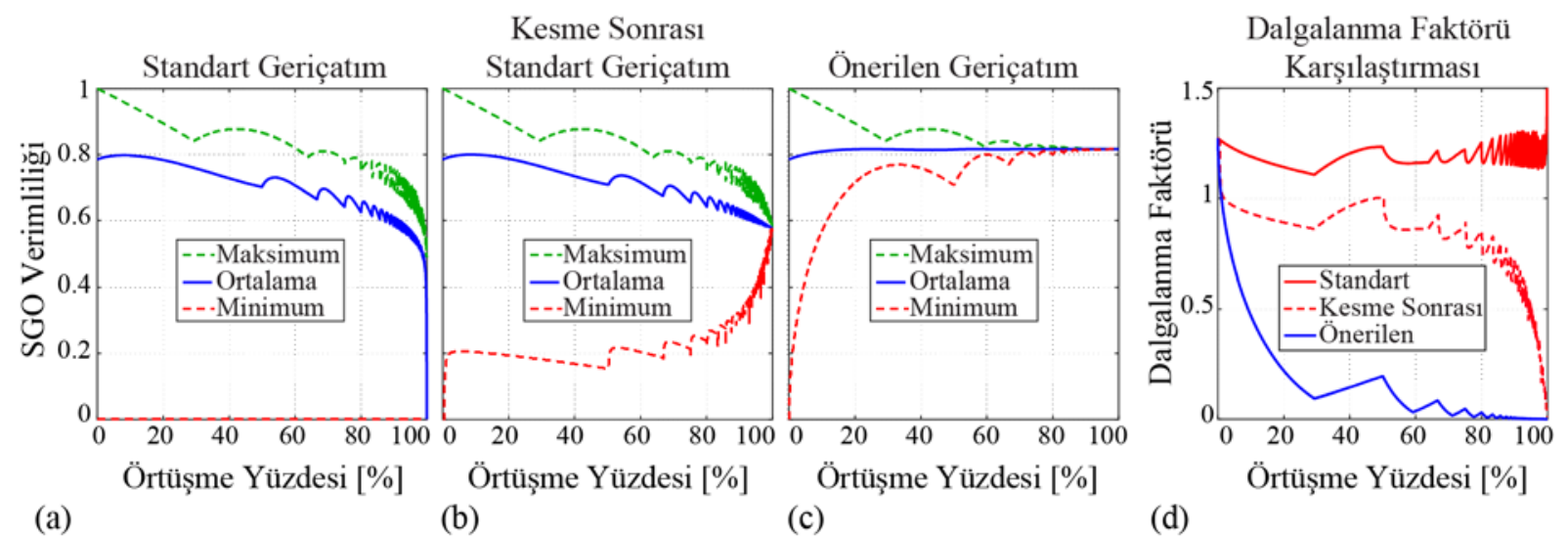

Şekil 4. Farklı örtüşme yüzdelerinde SGO verimliliği ve dalgalanma faktörü (a) Standart geriçatım (b) kesme sonrası standart geriçatım ve (c) önerilen geriçatım için minimum, maksimum ve ortalama SGO verimliliği (d) Her üç geriçatım tekniği için dalgalanma faktörü

(SNR efficiency and ripple factor for different overlap percentages SNR efficiency for (a) the standard reconstruction (b) the standard reconstruction after cutting and (c) the proposed reconstruction (d) Ripple factor for all three reconstruction techniques) 
dalgalanma faktörü her zaman 1'in üzerindedir. Kesme sonrası standart geriçatım için ise örtüşme yüzdesi \%86'dan azken 0,7'nin üzerinde kalmaktadır. Önerilen yöntemde ise örtüşme yüzdesi arttıkça dalgalanma faktörü hızla azalarak sıfıra inmektedir. Şekil 4d'ye göre örtüşme yüzdesi \%54'ü aştığında, önerilen yöntemin dalgalanma faktörü 0,1 'in altında kalmaktadır. Örtüşme \%80'i aştığında ise dalgalanma faktörü 0,03 'ün altına inmektedir.

\subsection{MPG Benzetimleri (MPI Simulations)}

MPG benzetimleri MATLAB ortamında kendi geliştirdiğimiz MPG benzetim paketi ile, 2,9 GHz Intel Core i5 işlemcili bilgisayarda gerçekleştirilmiştir. Benzetimlerde damar yapısını andıran sayısal bir fantom yaratılmış, ve gerçekçi sistem özellikleri ile oluşturulan NDF ile evrişimi sonucunda ideal MPG görüntüsü elde edilmiştir. $\mathrm{Bu}$ benzetimlerde Eş. 5'te verilen tek boyutlu NDF değil, üç boyutlu NDF kullanılmıştır [19]. MPG benzetimlerinde (x,y,z) yönlerinde $(-6,3,3) \mathrm{T} / \mathrm{m} / \mu 0$ gradyanda seçme alanı, ve son zamanlarda nanoparçacıklardaki gelişmelere göre gerçekçi bir rakam olan $25 \mathrm{~nm}$ çapında nanoparçacıklar [22] varsayılmıştır. Şekil 5a-c'de bu çalışmada kullanılan $5 \mathrm{~cm}$ x $5 \mathrm{~cm}$ büyüklüğündeki ve $1001 \times 1001$ pikselden oluşan sayısal fantom, NDF ve bu NDF'ye göre ideal MPG görüntüsü gösterilmektedir. Burada görüntü tarama yönü (yani eksitasyon alan yönü) ve sinyal alıcı bobin yönü z-yönü olarak seçilmiştir. Hem x-yönünde hem de z-yönünde zamana göre parçalı sabit odaklanma alanları varsayılmıştır [5]. Bu odaklanma alanları sayesinde MAB'ın merkezi X-Z düzleminde belirli bir kısmi görüş alanının merkezinde tutulurken, eksitasyon alanı kullanılarak o kısmi görüş alanı z-yönünde ileri geri taranır. Şekil 5d'deki şematikte gösterildiği gibi, bu işlem tüm kısmı görüş alanları için tekrarlanınca iki boyutlu görüntüleme sağlanmış olur. Sonuçta $\mathrm{x}$-yönünde kesikli, z-yönünde ise sürekli tarama elde edilmiş olur. Bu görüntü tarama tekniğinde kısmi görüş alanları z-yönünde uzandığı için, örtüşme de z-yönündedir. [5].

Şekil 5c'deki görüntüyü taramak için $25 \mathrm{kHz}$ te $10 \mathrm{mT} / \mu 0$ genliğinde ve $\mathrm{z}$-yönünde eksitasyon alanı kullanılmıştır. $\mathrm{Bu}$ eksitasyon alanı z-yönünde $6,67 \mathrm{~mm}$ genişliğinde bir kısmi görüş alanı kaplamaktadır. Odaklanma alanlarının şiddeti xyönünde $\pm 150 \mathrm{mT} / \mu 0$ arasında, z-yönünde $\pm 75 \mathrm{mT} / \mu 0$ arasında değişecek şekilde seçilmiştir. Böylece her iki yönde de $5 \mathrm{~cm}$ genişliğinde görüş alanı kaplanmıştır. İki boyutlu taramada x-yönü $0,5 \mathrm{~mm}$ aralıklarla (yani 100 farklı $\mathrm{x}$ değerinde) taranmıştır. Her bir kısmi görüş alanı için MPG sinyali Eş. 10 kullanılarak hesaplanmıştır ve $25 \mathrm{MHz}$ sinyal örnekleme frekansı varsayılmıştır. Önerilen yöntemin standart MPG geriçatımı ile karşılaştırılması için \%50 örtüşme ve $\% 80$ örtüşme seviyelerinde benzetimler gerçekleştirilmiştir. Bu benzetimler, $5 \mathrm{~dB}$ ve $40 \mathrm{~dB}$ değerleri arasında 8 farklı SGO seviyesinde MPG sinyali için tekrarlanmıştır. Burada SGO seviyesi, MPG görüntü alımında elde edilen en yüksek sinyal seviyesinin gürültü standart sapmasına oranı şeklinde tanımlanmıştır. İkincil olarak, daha gerçekçi koşullar elde etmek için nanoparçacıkların relaksasyon etkisi de benzetimlere dahil edilmiştir. MPG'de nanoparçacıklar manyetik alanın frekansına/genliğine ve nanoparçacıkların fiziksel özelliklerine bağlı olarak, uygulanan manyetik alanla anında hizalanamayabilirler. Bu gecikme "relaksasyon” olarak adlandırılır, ve Eş. 29 ve Eş. 30’da gösterildiği gibi ideal MPG sinyalinin üstel bir evrişim çekirdeği ile evrişimi olarak modellenir [23].

$$
\begin{aligned}
& s(t)=s_{\text {ideal }}(t) * r(t) \\
& r(t)=\frac{1}{\tau} e^{-t / \tau} u(t)
\end{aligned}
$$

Burada $u(t)$ Heaviside birim basamak fonksiyonu, $\tau$ ise relaksasyon zaman sabitidir. Basit görünen bu modelin deneysel sonuçlar ile yüksek seviyede uyumlu olduğu pek çok farklı frekans ve manyetik alan şiddetinde gerçekleştirilen deneyler ile gösterilmiştir [24]. Burada gerçekleştirdiğimiz benzetimlerde, seçilen eksitasyon frekansı olan $25 \mathrm{kHz}$ için gerçekçi bir değer olan $\tau=1 \mu \mathrm{s}$ zaman sabiti kullanılmıştır [24]. Yine $\% 50$ ve \%80 örtüşme seviyelerinde ve 5-40 $\mathrm{dB}$ arası 8 farklı SGO seviyesinde benzetimler gerçekleştirilmişti.

\section{6. İki Boyutlu Görüntü Geriçatımı ve Karşılaştırma için Alternatif Yöntemler \\ (Two-Dimensional Image Reconstruction and Alternative Techniques for Comparison)}

Benzetimlerde karşılaştırma yöntemi olarak iki farklı geriçatım kullanılmıştır:

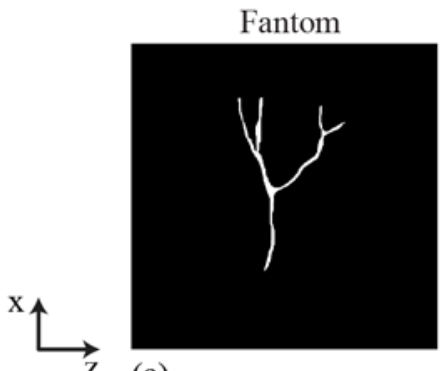

(a)

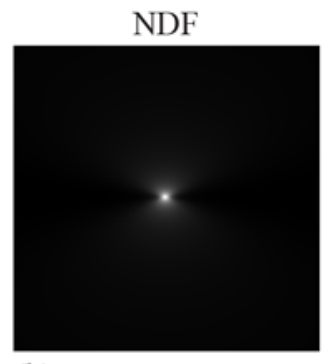

(b)

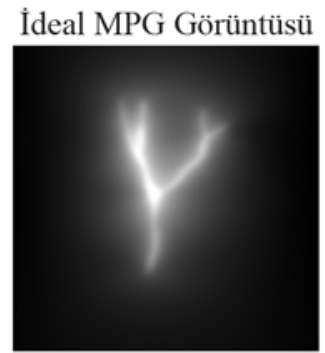

(c)

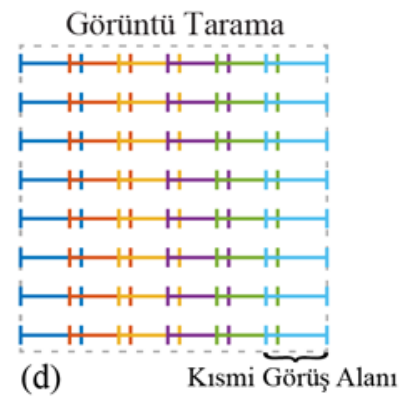

(d)
Kısmi Görüş Alanı

Şekil 5. (a) Benzetimlerde kullanılan $5 \mathrm{~cm}$ x $5 \mathrm{~cm}$ büyüklüğünde sayısal damar fantomu (b) MPG sisteminin nokta dağılım fonksiyonu (NDF) (c) İdeal MPG görüntüsü (d) İki boyutlu görüntü tarama şematiği ( (a) $5 \mathrm{~cm}$ x $5 \mathrm{~cm}$ digital phantom used in simulations (b) Point spread function (PSF) of the MPI system (c) Ideal MPI image (d) Schematic of two-dimensional scanning) 
- Standart Geriçatım: Bölüm 2'de anlatılan x-uzayı geriçatımı.

- Kesme Sonrası Standart Geriçatım: Bölüm 3.2'de anlatılan, kısmi görüş alanlarının yalnızca ortadaki \%95'lik kısmı kalacak şekilde SGO'su düşük olan iki ucunun kesilmesine dayanan geriçatım [5]. Bu kesme işlemi sonrasında yine standart $\mathrm{x}$-uzayı geriçatımı gerçekleştirilmektedir.

Tüm yöntemler için iki boyutlu görüntü geriçatımı, zyönünde sürekliliği zorlayan tek boyutlu geriçatımlardan oluşmaktadır. Bunun için öncelikle kısmi görüş alanlarının her iki ucundaki birer nokta atılmıştır. Her iki uçta tarama hızı tam olarak sıfıra düştüğü için, Eş. 11'de görüldüğü gibi sıfıra bölme sorunu ortaya çıkmaktadır. Kesme sonrası standart geriçatım için kesme işlemi, bu ön aşamadan hemen sonra uygulanmıştır. Sonrasında ise tüm yöntemler için DC kayıpları Bölüm 2.3'te anlatıldığı gibi hesaplanmıştır. DC kayıpları hesaplanırken, verilen bir x-değerindeki ilk kısmi görüş alanı olduğu gibi tutulmuş ve herhangi bir DC düzeltimi yapılmamıştır. İkinci kısmi görüş alanı, bu ilk görüş alanı ile örtüşen kısımlarda karşılaştırılmış, aralarındaki ortalama farktan DC kaybı hesaplanmış ve bu fark ikinci kısmi görüş alanına eklenmiştir. $\mathrm{Bu}$ işlemlerin diğer kısmi görüş alanları için de tekrarlanması ile o xdeğerindeki tüm kısmi görüş alanları birbiriyle uyumlu olacak seviyeye çekilmiştir. Kısmi görüş alanlarının birleştirilmesi için ise önerilen yöntem veya yukarıda listelenen iki yöntem kullanılmış ve böylece tek boyutlu görüntüler elde edilmiştir. Bu aşamaların taranan her bir xdeğeri için tekrarlanmasıyla iki boyutlu bir görüntü oluşturulmuştur. Nanoparçacık dağılımını veren MPG görüntüsünün negatif değere sahip olamayacağı bilindiği için, bu iki boyutlu görüntünün minimum değeri sıfira denk gelecek şekilde genel bir DC terimi eklenmiștir. Son olarak, x-yönünün kesikli ve z-yönünün sürekli olarak taranmış olmasından dolayı, bu iki yöndeki piksel boyutunu eșitlemek için lineer aradeğerleme kullanılmıştır. Böylece 1001x1001 pikselden oluşan iki boyutlu görüntüler elde edilmiştir.

Yukarıda listelenen iki yöntemin önerilen yöntem ile karşılaştırılması için, doruk sinyal gürültü oranı (DSGO) ve yapısal benzerlik indeksi (YBİ) adlı iki farklı görüntü kalitesi metriği kullanılmıştır. DSGO, Eş. 31'deki gibi hesaplanmaktadır.

$D S G O=10 \log _{10} \frac{\max \left(I M G_{\text {ideal }}\right)^{2}}{\frac{1}{M N} \sum_{i=1}^{M} \sum_{j=1}^{N}\left(I M G_{\text {ideal }}(\mathrm{i}, \mathrm{j})-I M G(\mathrm{i}, \mathrm{j})\right)^{2}}$

Burada $I M G_{\text {ideal }}$, gürültü ve relaksasyon olmadığ 1 durumlarda elde edilen ideal x-uzayı MPG görüntüsü, $I M G$ ise geriçatım sonrası elde edilen MPG görüntüsüdür. Kısaca, DSGO metriği iki görüntü arasındaki ortalama karesel hatayı, referans görüntüsünün en yüksek değerinin karesiyle oranlar. Böylece farklı koşullar altında bile anlamlı bir sayısal değer elde edilmesini sağlar. Buna göre, yüksek DSGO değeri daha kaliteli görüntüye işaret etmektedir. YBİ ise iki görüntünün görsel benzerliklerini karşılaştırmaya yarayan bir metriktir. $\mathrm{Bu}$ metrik görüntülerin parlaklık, kontrast ve yapı özelliklerinin birlikte değerlendirilmesi ile elde edilir, ve en yaygın kullanımı ile matematiksel olarak Eş. 32'deki gibi ifade edilir [25].

$Y B \dot{\mathrm{I}}=\frac{1}{M N} \sum_{i=1}^{M} \sum_{j=1}^{N}$
$\frac{\left(2 \mu_{\text {ideal }}(\mathrm{i}, \mathrm{j}) \mu_{I M G}(\mathrm{i}, \mathrm{j})+\beta_{1}\right)\left(2 \sigma_{\text {ideal } I M G}(\mathrm{i}, \mathrm{j})+\beta_{2}\right)}{\left(\mu_{\text {ideal }}^{2}(\mathrm{i}, \mathrm{j})+\mu_{I M G}^{2}(\mathrm{i}, \mathrm{j})+\beta_{1}\right)\left(\sigma_{\text {ideal }}^{2}(\mathrm{i}, \mathrm{j})+\sigma_{I M G}^{2}(\mathrm{i}, \mathrm{j})+\beta_{2}\right)}$

Burada $\mu_{\text {ideal }}(i, j)$ ve $\mu_{I M G}(i, j)$ sırasıyla normalize edilmiş $I M G_{\text {ideal }}$ ve $I M G$ görüntülerinin $(i, j)$ pikseli etrafindaki yerel ortalamalarını, $\sigma_{\text {ideal }}(i, j)$ ve $\sigma_{I M G}(i, j)$ aynı görüntülerin $(i, j)$ pikseli etrafındaki yerel standart sapmalarını, $\sigma_{\text {ideal,IMG }}(i, j)$ ise bu iki görüntünün $(i, j)$ pikseli etrafındaki yerel çapraz kovaryansını ifade eder. $\beta_{1}$ ve $\beta_{2}$ düzenlileştirme sabitleridir, ve bu çalışmada MATLAB'daki varsayılan değerleri olan $\beta_{1}=1 \times 10^{-4}$ ve $\beta_{2}=9 \times 10^{-4}$ kullanılmıștır. Yerel istatistiklerin hesaplanması içinse eşyönlü Gauss fonksiyonu kullanılarak her piksel ve çevresindeki pikseller ağırlıklandırılmıştır. $\mathrm{Bu}$ Gauss fonksiyonunun standart sapması için MATLAB'daki varsayılan değeri olan 1,5 kullanılmıştır. Eş. 32 'de ifade edildiği üzere, YBİ ile öncelikle yerel yapısal benzerlikler hesaplanmakta ve sonrasında tüm görüntü üzerinde bir ortalama alınmaktadır. $\mathrm{Bu}$ çalışmada gösterim kolaylığı için YBİ sonuçları yüzdelik değer olarak ifade edilmiştir. Buna göre YBİ'nin en yüksek değeri olan \%100 (yani Eş. 32'de YBİ = 1), ideal görüntü ile birebir aynı görüntü elde edildiği anlamına gelmektedir. Burada Monte Carlo benzetimleri gerçekleștirmiş ve bunun için benzetimler her gürültü seviyesinde 10 kere tekrarlanmıştır. Daha güvenilir sonuçlar elde etmek için bu 10 tekrardan elde edilen DSGO değerlerinin ortalamas1 alınmıştır. Aynı aşamalar ortalama YBİ hesaplaması için tekrarlanmıştır.

\section{SONUÇLAR VE TARTIŞMALAR (RESULTS AND DISCUSSIONS)}

Şekil 6'da \%50 örtüşme seviyesinde, 3 farklı SGO seviyesinde $(30,15,10 \mathrm{~dB})$ elde edilen görüntüler gösterilmektedir. Bu şekilde, tüm görüntülerin parlaklık ve kontrast seviyeleri aynı olacak şekilde ayarlanmıştır. MPG sinyalinin SGO'su yeterince yüksek olduğunda (örneğin 30 dB) önerilen yöntem, standart geriçatım ve kesme sonrası standart geriçatım görsel olarak herhangi bir farklılık göstermemektedir. Öte yandan, SGO seviyesi 15 dB iken standart geriçatımda dikey yönde periyodik aralıklarla çizgi artefaktları oluşmaktadır. Bu çizgiler her bir kısmi görüş alanının iki ucunda SGO'nun sıfıra düştüğü konumlara denk gelmektedir. Kesme sonrası standart geriçatımda bu dikey çizgiler görece azalmış olsa da halen gözle görülür seviyededir. SGO seviyesi $10 \mathrm{~dB}$ 'ye düştüğünde hem standart geriçatım hem de kesme sonrası standart geriçatımda dikey çizgilerin şiddeti artmaktadır. Önerilen yöntemde ise hem $15 \mathrm{~dB}$ hem de $10 \mathrm{~dB}$ SGO seviyelerinde bu dikey çizgi artefaktı görünmemektedir. Şekil 6'da görüldüğü gibi, SGO seviyesi düştükçe her üç geriçatımda da yatay yönde çizgiler oluşmaktadır. Bu çizgilerin sebebi, taramanın ve sonrasında görüntü geriçatımının yatay yönde çizgiler halinde yapılmış olmasıdır. Birbirine komşu iki 


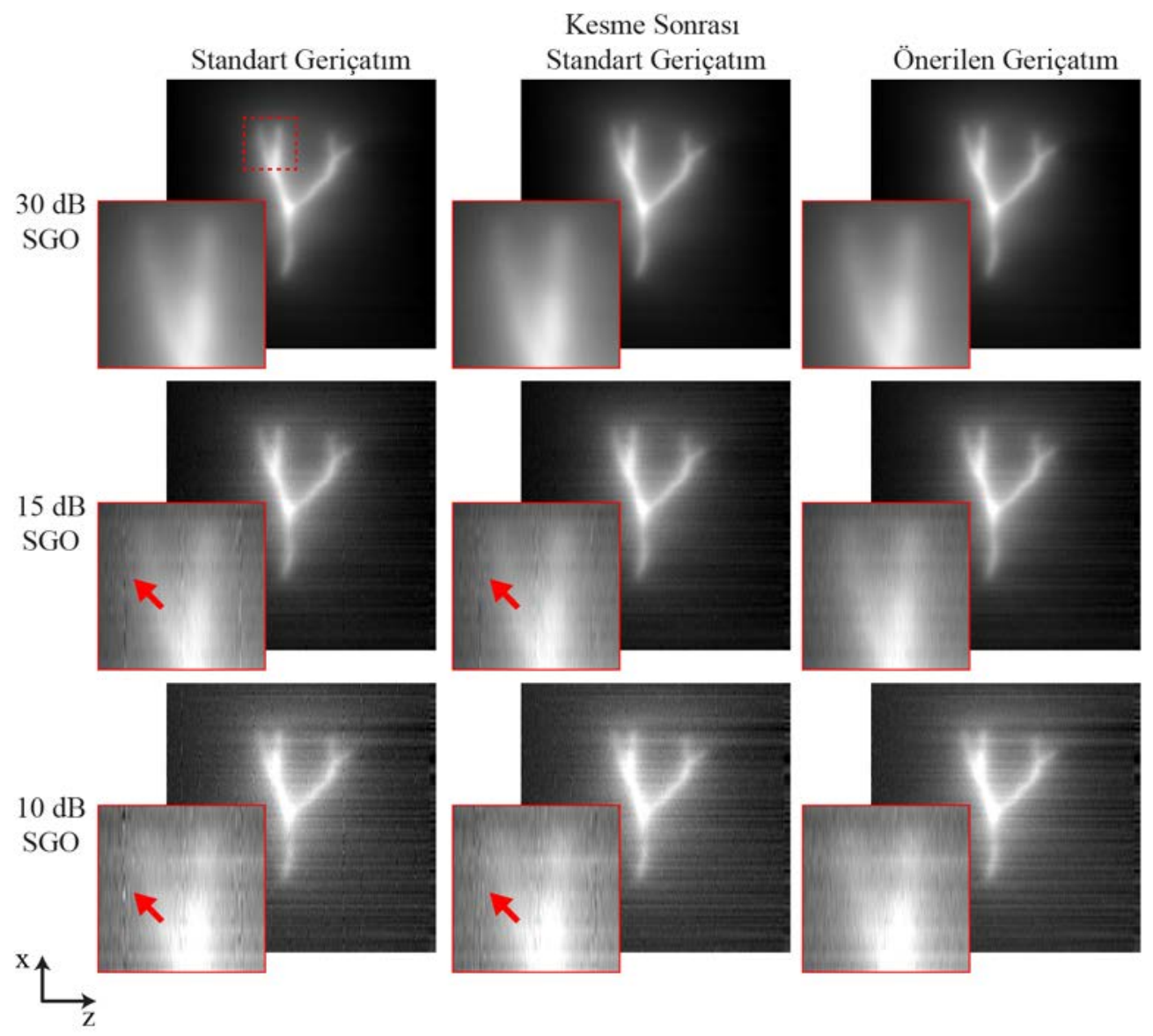

Şekil 6. \%50 örtüşme seviyesinde, üç farklı SGO seviyesinde MPG sinyali için elde edilen görüntü geriçatım sonuçları (Image reconstruction results obtained for MPI signals at 50\% overlap and three different SNR levels)

Tablo 1. \%50 örtüşme seviyesinde, 8 farklı SGO seviyesinde görüntü geriçatım sonuçlarının doruk sinyal gürültü oranı (DSGO) ve yapısal benzerlik indeksi (YBI) karşılaştırmaları (Peak signal-to-noise ratio and structural similarity index comparisons for image reconstruction results obtained at 50\% overlap and 8 different SNR levels)

\begin{tabular}{|c|c|c|c|c|c|c|c|c|c|}
\hline & & \multicolumn{8}{|c|}{ MPG Sinyal Seviyesi } \\
\hline & & $40 \mathrm{~dB}$ & $35 \mathrm{~dB}$ & $30 \mathrm{~dB}$ & $25 \mathrm{~dB}$ & $20 \mathrm{~dB}$ & $15 \mathrm{~dB}$ & $10 \mathrm{~dB}$ & $5 \mathrm{~dB}$ \\
\hline Standart & DSGO & 53,74 & 49,56 & 43,47 & 38,60 & 31,66 & 29,47 & 22,37 & 18,52 \\
\hline Geriçatım & YBİ & 99,83 & 99,50 & 98,43 & 95,45 & 87,17 & 74,92 & 50,38 & 27,69 \\
\hline Kesme & DSGO & 54,19 & 50,06 & 43,85 & 39,04 & 31,94 & 29,88 & 22,60 & 18,83 \\
\hline Sonras1 & YBİ & 99,86 & 99,58 & 98,68 & 96,03 & 88,13 & 76,07 & 51,16 & 28,05 \\
\hline Önerilen & DSGO & 55,06 & 51,11 & 44,63 & 39,97 & 32,51 & 30,72 & 23,15 & 19,53 \\
\hline Geriçatım & YBİ & 99,90 & 99,72 & 99,11 & 97,25 & 91,11 & 81,74 & 57,87 & 32,90 \\
\hline
\end{tabular}

çizginin geriçatımı sırasında gürültüden kaynaklı bir parlaklık uyuşmazlı̆̆g olduğunda, en son görüntüde bu yatay çizgiler oluşmaktadır. Önerilen geriçatım bu yatay çizgileri gideremese de, dikey yöndeki çizgilerden başarıyla kurtulmayı sağlamıştır. Tablo 1'de \%50 örtüşme seviyesi için 5-40 $\mathrm{dB}$ arasında 8 farklı $\quad$ SGO seviyesinde gerçekleştirilen benzetimlerden elde edilen DSGO ve YBI değerleri verilmiştir. Bu değerler her bir SGO seviyesinde 10 farklı Monte Carlo benzetimi sonrası elde edilen değerlerin ortalamasını göstermektedir. Buna göre önerilen yöntem tüm SGO seviyelerinde en yüksek DSGO ve YBİ değerini vermektedir. Önerilen yöntem tüm SGO değerlerinde 1008 standart geriçatıma göre ortalamada 1,16 dB daha yüksek DSGO'ya ve \%3,28 daha yüksek YBİ'ye sahiptir. Önerilen yöntem ile standart geriçatımın arasındaki DSGO farkı tüm SGO seviyelerinde yaklaşı 1-1,5 dB arasında seyrederken, YBİ fark1 ise SGO seviyesi $15 \mathrm{~dB}$ 'den düşükken \%5-\%8 seviyelerine kadar çıkmaktadır. Kesme sonrası standart geriçatıma göre ise önerilen yöntem ortalamada $0,78 \mathrm{~dB}$ daha yüksek DSGO'ya ve \%2,76 daha yüksek YBİ'ye sahiptir. Önerilen geriçatım tüm SGO seviyelerinde kesme sonrası geriçatıma göre $0.5-1 \mathrm{~dB}$ daha yüksek DSGO'ya sahipken, SGO seviyesi $15 \mathrm{~dB}$ 'den düşükken \%5-\%7 daha yüksek YBI'ye sahiptir. Şekil 7'de \%80 örtüşmede, 3 farklı 


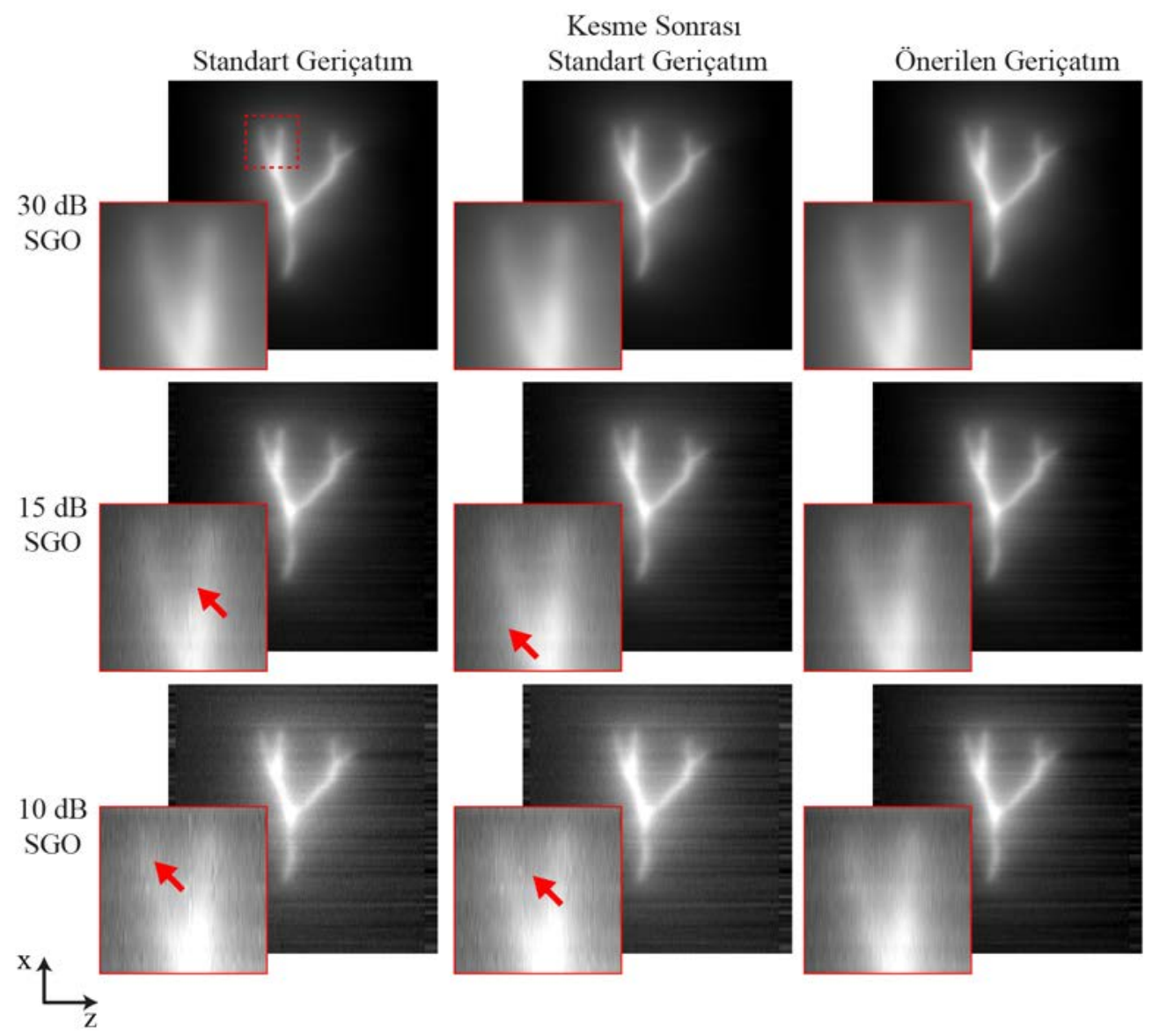

Şekil 7. \%80 örtüşme seviyesinde üç farklı SGO seviyesinde MPG sinyali için elde edilen görüntü geriçatım sonuçları (Image reconstruction results obtained for MPI signals at $80 \%$ overlap and three different SNR levels)

SGO seviyesi $(30,15,10 \mathrm{~dB})$ için geriçatım sonuçları gösterilmiştir. Sonuçlar genel olarak Şekil 6'da \%50 örtüşme için verilene benzer eğilimler göstermektedir. $30 \mathrm{~dB}$ SGO durumunda sinyal kalitesi yüksek olduğu için her üç geriçatım da görsel olarak benzer sonuçlar vermektedir. Daha düşük $15 \mathrm{~dB}$ SGO seviyesinde standart geriçatım ve kesme sonrası standart geriçatımda dikey çizgi artefaktları belirmektedir. Daha yüksek örtüşme oranı kullanıldığı için komşu kısmi görüş alanları birbirine daha yakındır; bu nedenle dikey çizgiler Şekil 6'dakilere göre daha sık aralıklarla belirmektedir. En düşük $10 \mathrm{~dB}$ SGO seviyesinde ise bu artefaktlar güçlenirken, ikincil bir sorun daha ortaya çıkmaktadır: Standart geriçatım ve kesme sonrası standart geriçatımda arka plan gürültü seviyesi önemli ölçüde artmaktadır. Buna karşın önerilen geriçatımda arka plan gürültüsü daha düşüktür ve dikey çizgi artefaktları yoktur.

Tablo 2'de ise \%80 örtüşme seviyesinde 5-40 dB arasındaki SGO seviyelerinde elde edilen geriçatımların nicel karşılaştırması için DSGO ve YBİ sonuçları verilmiştir. Yine bu değerlerin her biri 10 farklı benzetimden elde edilen sonuçların ortalamasını göstermektedir. Önerilen yöntem tüm SGO değerlerinde diğer iki yönteme göre daha yüksek DSGO ve YBI vermektedir. Aradaki fark \%50 örtüşme seviyesindeki farka göre daha yüksektir. Önerilen yöntem tüm SGO değerlerinde ortalamada standart geriçatıma göre
3,34 dB daha yüksek DSGO ve \%4,98 daha yüksek YBİ'ye sahiptir. SGO seviyesi $15 \mathrm{~dB}$ altına düştüğünde önerilen yöntem YBİ'de \%12-\%14 seviyelerinde bir artış sağlamaktadır. Kesme sonrası standart geriçatıma göre ise, önerilen yöntem ortalamada 3,09 dB daha yüksek DSGO ve $\% 4,16$ daha yüksek YBİ vermektedir. SGO seviyesi $15 \mathrm{~dB}$ altındayken YBI'deki iyileşme \%10-\%12 seviyelerine çıkmaktadır.

Son olarak, Şekil 8'de MPG sinyaline nanoparçacık relaksasyon etkisinin de dahil edildiği benzetimlerin sonuçları $\% 50$ ve $\% 80$ örtüşme seviyeleri için, ve görece düşük $15 \mathrm{~dB}$ ve $10 \mathrm{~dB}$ SGO değerlerinde verilmiştir. $\mathrm{Bu}$ sonuçlardaki eğilimler Şekil 6 ve 7'dekilerle uyumludur. SGO seviyesi düştükçe standart geriçatım ve kesme sonrası standart geriçatımda dikey çizgi artefaktları oluşmaktadır. $\mathrm{Bu}$ artefaktlar özellikle \%50 örtüşme durumunda daha belirgindir. Önerilen geriçatımla dikey çizgi artefaktları giderilmiştir. Relaksasyon etkisinin dahil edildiği durumda ideal görüntünün teorik bir formülasyonu yoktur ve görüntüyü elde etmenin tek yolu geriçatım uygulamaktır. $\mathrm{Bu}$ nedenle bu görüntülerde nicel DSGO ve YBİ karşılaştırması yapılmamıştır.

Önerilen yöntem tüm SGO değerlerinde standart geriçatım ve kesme sonrası standart geriçatıma göre, hem görsel olarak 
Tablo 2. \%80 örtüşme seviyesinde 8 farklı SGO seviyesinde görüntü geriçatım sonuçlarının doruk sinyal gürültü oranı (DSGO) ve yapısal benzerlik indeksi (YBİ) karşılaştırmaları (Peak signal-to-noise ratio and structural similarity index comparisons for image reconstruction results obtained at $80 \%$ overlap and 8 different SNR levels)

\begin{tabular}{|c|c|c|c|c|c|c|c|c|c|}
\hline & \multicolumn{8}{|c|}{ MPG Sinyal Seviyesi } \\
\hline & & $40 \mathrm{~dB}$ & $35 \mathrm{~dB}$ & $30 \mathrm{~dB}$ & $25 \mathrm{~dB}$ & $20 \mathrm{~dB}$ & $15 \mathrm{~dB}$ & $10 \mathrm{~dB}$ & $5 \mathrm{~dB}$ \\
\hline Standart & DSGO & 54,79 & 51,51 & 46,45 & 40,23 & 35,35 & 29,52 & 23,09 & 20,35 \\
\hline Geriçatım & YBİ & 99,88 & 99,76 & 99,21 & 97,44 & 93,27 & 82,07 & 60,86 & 38,31 \\
\hline Kesme & DSGO & 55,04 & 51,84 & 46,81 & 40,51 & 35,61 & 29,74 & 23,20 & 20,57 \\
\hline Sonras1 & YBİ & 99,89 & 99,79 & 99,31 & 97,73 & 94,05 & 83,68 & 62,89 & 40,00 \\
\hline Önerilen & DSGO & 57,64 & 54,48 & 49,71 & 45,29 & 37,72 & 35,00 & 26,17 & 22,00 \\
\hline Geriçatım & YBİ & 99,95 & 99,86 & 99,65 & 98,95 & 96,40 & 90,98 & 74,55 & 50,32 \\
\hline
\end{tabular}

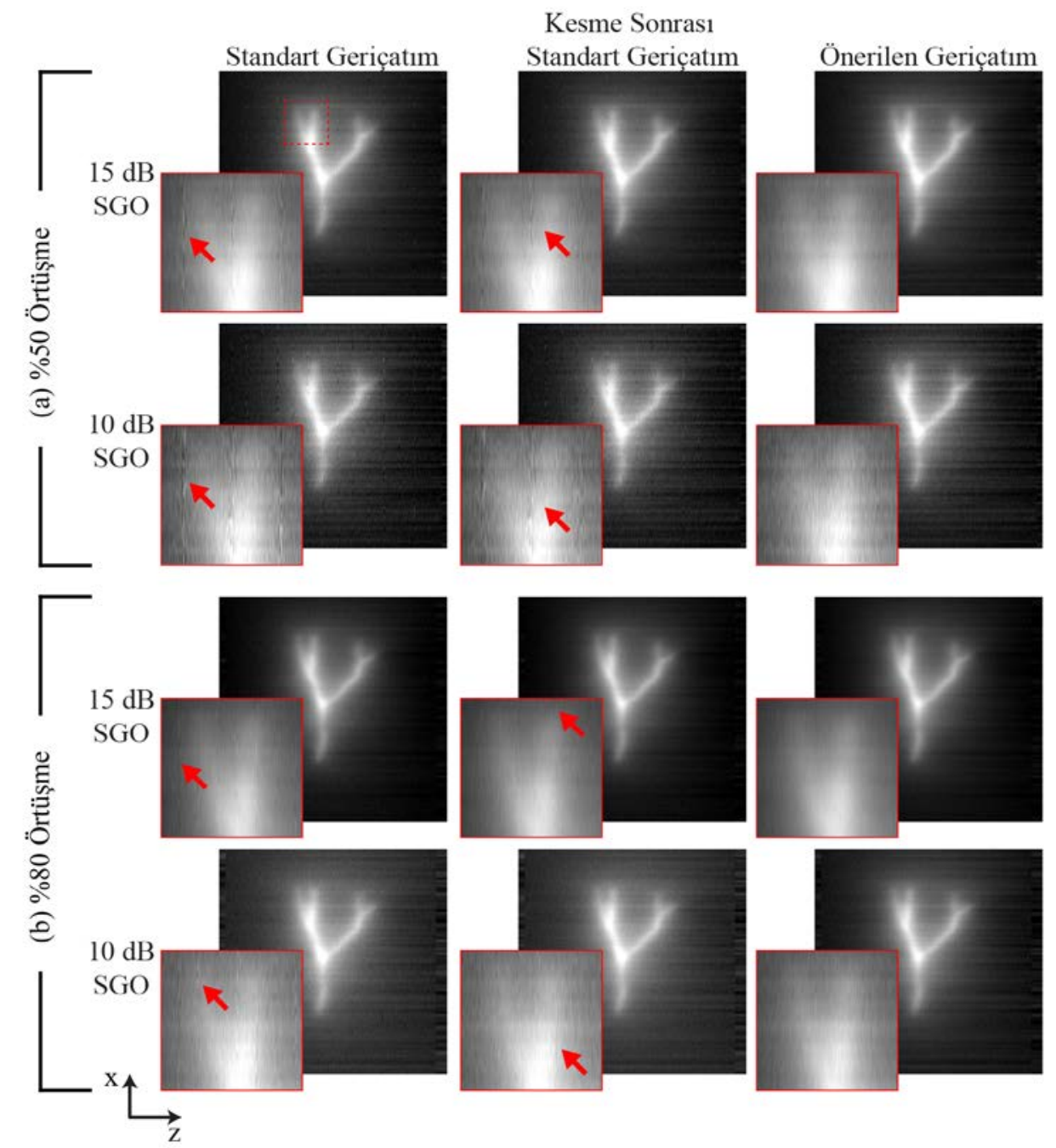

Şekil 8. MPG sinyaline nanoparçacık relaksasyon etkisinin dahil edildiği durum için $\% 50$ ve $\% 80$ örtüşme seviyelerinde iki farklı SGO seviyesinde görüntü geriçatım sonuçları

(Image reconstruction results when the relaxation effect is incorporated into the MPI signal at 50\% and 80\% overlap and two different SNR levels)

hem de nicel DSGO ve YBİ ölçütlerine göre, görüntü kalitesinde artış sağlamaktadır. Kesim sonrası standart geriçatım da normal geriçatıma göre görsel bir iyileşme sağlasa da, dikey çizgileri tamamen giderememektedir. Önerilen geriçatım ise herhangi bir veri atımı gerektirmeden bu dikey çizgi artefaktlarından kurtulmayı sağlamaktadır. Öte yandan, her üç geriçatım için de düşük SGO 1010 seviyelerinde yatay yönde çizgiler gözlemlenmektedir. Bu çizgilerin nedeni, görüntü taramasının yatay yönde olması ve o yönde görüntü sürekliliğinin geriçatım sırasında zorlanmasıdır. Bölüm 3.6'da anlatılan iki boyutlu görüntü geriçatımı, gürültünün düşük olduğu durumlarda dikey yönde de sürekliliği olan MPG görüntüleri vermektedir. Gürültü seviyesi arttıkça, her bir x-değeri için tek boyutlu 
görüntülerin bağımsız geriçatılması, yatay yönde çizgi artefaktlarına neden olmaktadır. Bir sonraki aşama olarak her iki yönde de görüntü sürekliliği sağlayan bir geriçatım tekniği geliştirmeyi hedeflemekteyiz.

Bu çalışmada kısmi görüş alanlarının SGO’yu eniyileyecek şekilde ağırlıklandırılarak birleştirilmesine dayalı bir yöntem önerilmiştir. Benzer bir yöntem DC kayıplarının hesaplanması sırasında da uygulanabilir. Standart DC kayıp hesaplama yönteminde, iki komşu kısmi görüş alanının örtüşen kısımları arasındaki farkın ortalaması alınmaktadır. Oysa ki kısmi görüş alanlarının kenarlarına doğru SGO düştüğü için, örtüşen bölgenin her iki kenarında hesaplanan farkın gürültü seviyesi yüksektir. Ortalama fark hesaplanırken SGO'yu eniyileyebilmek için, her konumda hesaplanan fark, o konumdaki “farkın SGO'su”nun karesi ile ağırlıklandırılmalıdır. Bu işlem, farkı alınan iki değerin SGO'larının karelerinin harmonik ortalaması ile ağırlıklandırma ile eşdeğerdir. Bu ağırlıklandırma, örtüşen kısmın iki kenarında sıfıra gitmekte ve tam ortada en yüksek değere ulaşmaktadır. Gerçekleştirdiğimiz ön benzetim sonuçlarına göre bu yöntem görüntülerde gözle görülür bir iyileşme sağlamamaktadır. Bunun iki nedeni olduğunu düşünmekteyiz: Birincisi, sözü edilen ağırlıklandırma konuma bağlı olarak görece yavaş değişen bir fonksiyondur (özellikle örtüşme oranı \%50 altındayken). İkincisi, DC kaybı hesabında ufak hatalar olsa dahi, kısmi görüş alanlarından elde edilen görüntülerin birleştirilmesi sırasında gerçekleştirilen ortalama alma işlemi bu hataların etkisini azaltmaktadır. $\mathrm{Bu}$ yöntemin özellikle yüksek örtüşme seviyelerindeki etkisi, ileride daha detaylı incelemeyi hedeflediğimiz bir konudur.

\section{SONUÇLAR (CONCLUSIONS)}

Yeni bir biyomedikal görüntüleme olan MPG'de eksitasyon manyetik alanının genliği, insan güvenlik sınırları tarafından kısıtlanmaktadır. Bu nedenle görüntülenmek istenen bölge kısmi görüş alanlarına bölünerek ufak parçalar halinde taranır. Bu çalışmada bu kısmi görüş alanlarını SGO’yu eniyileyecek şekilde birleştirmek için bir geriçatım yöntemi önerilmiştir. $\mathrm{Bu}$ yöntemde birbiriyle örtüşen kısmi görüş alanlarından elde edilen görüntülerin ortalaması alınmadan önce, her bir kısmi görüş alanından elde edilen görüntü konuma bağlı olarak değişen tarama hızının karesi ile ağırlıklandırılmalıdır. Farklı örtüşme yüzdelerinde, farklı SGO seviyelerinde ve nanoparçacıklarının relaksasyon etkisinin de dahil edildiği durumlarda, önerilen yöntem standart MPG geriçatımlarının neden olduğu dikey çizgilerden kurtulmayı sağlamakta ve görüntü kalitesini artırmaktadır.

\section{SIMGELER (SYMBOLS)}

\section{Latin Harfleri (Latin Letters)}

$c_{i} \quad$ Indeksi $i$ olan kısmi görüş alanına verilen ağırlık

$d \quad$ Nanoparçacık manyetik çekirdek çapı

DF Dalgalanma faktörü

\begin{tabular}{|c|c|}
\hline$f_{0}$ & Eksitasyon manyetik alanı frekansı \\
\hline$G$ & Seçme manyetik alanının $\mathrm{x}$ gradyanı \\
\hline$h$ & MPG sisteminin nokta dağılım fonsiyonu \\
\hline$H$ & Uygulanan manyetik alan \\
\hline$H_{e}$ & Eksitasyon manyetik alanı \\
\hline$H_{\text {odak }}$ & Odaklanma manyetik alanı \\
\hline$H_{s}$ & Seçme manyetik alanı \\
\hline$H_{\text {sat }}$ & $\begin{array}{l}\text { Nanoparçacığı yarı doygunluğa ulaştırmak için } \\
\text { uygulanması gereken manyetik alan }\end{array}$ \\
\hline$H_{0}$ & Eksitasyon manyetik alanı genliği \\
\hline$I M G$ & MPG görüntüsü \\
\hline$I M G_{i}$ & $\begin{array}{l}\text { İndeksi } i \text { olan kısmi görüş alanının ideal } \\
\text { görüntüsü }\end{array}$ \\
\hline$I M G_{i}{ }^{\prime}$ & $\begin{array}{l}\text { DC değer kaybı sonrası indeksi i olan kısmi } \\
\text { görüş alanın görüntüsü }\end{array}$ \\
\hline$I M G_{i d e a l}$ & $\begin{array}{l}\text { Gürültü ve relaksasyon olmadığı durumlarda } \\
\text { elde edilen ideal x-uzayı MPG görüntüsü }\end{array}$ \\
\hline$K$ & $\begin{array}{l}\text { Herhangi bir } x_{s} \text { konumundan geçen kısmi görüş } \\
\text { alanı sayısı }\end{array}$ \\
\hline$k_{B}$ & Boltzmann sabiti \\
\hline $\mathcal{L}$ & $\begin{array}{l}\text { Nanoparçacık miknatıslanma eğrisini veren } \\
\text { Langevin fonksiyonu }\end{array}$ \\
\hline$M$ & Nanoparçacık mıknatıslanması \\
\hline$m_{s}$ & Nanoparçacık doygunluk manyetik momenti \\
\hline$M_{S}$ & Nanoparçacık doyum mıknatıslanması \\
\hline$n_{i}$ & Toplanır gürültü \\
\hline$r$ & Relaksasyon etkisini belirten evrişim çekirdeği \\
\hline$S$ & Relaksasyon etkisi katılmış MPG sinyali \\
\hline$S_{\text {ideal }}$ & $\begin{array}{l}\text { İdeal MPG sinyali (gürültü ve relaksasyon etkisi } \\
\text { katılmamış) }\end{array}$ \\
\hline$T$ & Mutlak sicaklik \\
\hline$u$ & Heaviside birim basamak fonksiyonu \\
\hline$W$ & Kısmi görüş alanı genişliği \\
\hline$x_{s}$ & MAB'in konumu \\
\hline$\dot{x}_{s}$ & MAB'ın tarama hızı \\
\hline
\end{tabular}

Yunan Harfleri (Greek Letters)

\begin{tabular}{|c|c|}
\hline$\alpha_{i}$ & $\begin{array}{l}\text { İndeksi } i \text { olan kısmi görüş alanının maruz } \\
\text { kaldığı DC değer kaybı }\end{array}$ \\
\hline$\beta_{1}, \beta_{2}$ & YBI'de düzenlileștirme sabitleri \\
\hline$\gamma$ & $\begin{array}{l}\text { Endüktif bobinin hassasiyetine, } \\
\text { nanoparçacıkların manyetik özelliklerine ve } \\
\text { MPG tarayıcının seçme alanının gradyanına } \\
\text { bağlı bir sabit }\end{array}$ \\
\hline$\Delta x$ & MPG çözünürlüğü (yar1-doruk genişliği) \\
\hline$\mu_{0}$ & Vakum geçirgenliği \\
\hline$\mu_{i d e a l}$ & $\begin{array}{l}\text { Normalize edilmiş } I M G_{\text {ideal }} \text { görüntüsünün } \\
\text { yerel ortalaması }\end{array}$ \\
\hline$\mu_{I M G}$ & $\begin{array}{l}\text { Normalize edilmiş } I M G \text { görüntüsünün yerel } \\
\text { ortalaması }\end{array}$ \\
\hline$\rho$ & Nanoparçacıkların uzamsal dağılım yoğunluğu \\
\hline$\hat{\rho}$ & $\begin{array}{l}\text { Nanoparçacıkların uzamsal dağılım } \\
\text { yoğunluğunun ideal MPG görüntüsü }\end{array}$ \\
\hline$\sigma$ & Toplanır gürültü standart sapması \\
\hline$\sigma^{\prime}$ & $\begin{array}{l}\text { Birleştirilmiş görüntüdeki gürültü standart } \\
\text { sapması }\end{array}$ \\
\hline$\sigma_{i d e a l}$ & $\begin{array}{l}\text { Normalize edilmiş } I M G_{\text {ideal }} \text { görüntüsünün } \\
\text { yerel standart sapması }\end{array}$ \\
\hline
\end{tabular}




$\begin{array}{ll}\sigma_{I M G} & \begin{array}{l}\text { Normalize edilmiş } I M G \text { görüntüsünün yerel } \\ \text { standart sapması }\end{array} \\ \sigma_{\text {ideal }, I M G} & \begin{array}{l}\text { Normalize edilmiş } I M G_{\text {ideal }} \text { ve } I M G \\ \text { görüntülerinin yerel çapraz kovaryansı } \\ \text { Relaksasyon zaman sabiti }\end{array}\end{array}$

Kisaltmalar (Abbreviations)

DSGO Doruk sinyal-gürültü oranı

MAB Manyetik alansız bölge

MPG Manyetik parçacık görüntüleme

NDF Nokta dağılım fonsiyonu

NSGO Normalize edilmiş sinyal-gürültü oranı

SGO Sinyal-gürültü oranı

VSGO Sinyal-gürültü oranı verimliliği

YBİ Yapisal benzerlik indeksi

\section{TEŞEKKÜR (ACKNOWLEDGEMENTS)}

Bu çalışma Avrupa Birliği FP7 Marie Curie CIG fonu (PCIG13-GA-2013-618834), Türkiye Bilimler Akademisi TÜBA-GEBİP 2015 Ödülü ve Bilim Akademisi BAGEP Ödülü ile desteklenmiştir. MPG MATLAB benzetim paketine olan katkıları için Ömer Burak Demirel'e ve Yavuz Muslu'ya teşekkür ederiz.

\section{KAYNAKLAR (REFERENCES)}

1. Gleich B., Weizenecker J., Tomographic imaging using the nonlinear response of magnetic particles, Nature, 435 (7046), 1214-1217, 2005.

2. Saritas E.U., Goodwill P.W., Croft L.R., Konkle J.J., Lu K., Zheng B., Conolly S.M., Magnetic particle imaging (MPI) for NMR and MRI researchers, Journal of Magnetic Resonance, 229, 116-126, 2013.

3. Goodwill P.W., Saritas E.U., Croft L.R., Kim T.N., Krishnan K.M., Schaffer D.V., Conolly S.M., X-space MPI: magnetic nanoparticles for safe medical imaging, Advanced Materials, 24 (28), 3870-3877, 2012.

4. Weizenecker J., Gleich B., Rahmer J., Dahnke H., Borgert J., Three-dimensional real-time in vivomagnetic particle imaging, Physics in Medicine \& Biology, 54 (5), L1-L10, 2009.

5. Lu K., Goodwill P.W., Saritas E.U., Zheng B., Conolly S.M., Linearity and shift invariance for quantitative magnetic particle imaging, IEEE Transactions on Medical Imaging, 32 (9), 1565-1575, 2013.

6. Zheng B., Vazin T., Goodwill P.W., Conway A., Verma A., Saritas E.U., Schaffer D., Conolly S.M., Magnetic Particle Imaging tracks the long-term fate of in vivo neural cell implants with high image contrast, Scientific Reports, 5, 14055, 2015.

7. Them K., Salamon J., Szwargulski P., Sequeira S., Kaul M.G., Lange C., Ittrich H., Knopp T., Increasing the sensitivity for stem cell monitoring in system-function based magnetic particle imaging, Physics in Medicine \& Biology, 61 (9), 3279-3290, 2016.

8. Yu E.Y., Bishop M., Zheng B., Ferguson R.M., Khandhar A.P., Kemp S.J., Krishnan K.M., Goodwill
P.W., Conolly S.M., Magnetic Particle Imaging: A Novel in Vivo Imaging Platform for Cancer Detection, Nano Letters, 17 (3), 1648-1654, 2017.

9. Rahmer J., Halkola A., Gleich B., Schmale I., Borgert J., First experimental evidence of the feasibility of multi-color magnetic particle imaging, Physics in Medicine \& Biology, 60 (5), 1775-1791, 2015.

10. Utkur M., Muslu Y., Saritas E.U., Relaxation-based viscosity mapping for magnetic particle imaging, Physics in Medicine \& Biology, 62 (9), 3422-3439, 2017.

11. Selvi E., Selver M.A., Kavur A.E., Güzeliş C., Dicle O., Segmentation of Abdominal Organs from MR Images Using Multi-level Hierarchical Classification, Journal of the Faculty of Engineering and Architecture of Gazi University, 30 (3), 533-546, 2015.

12. Kaya H., Çavuşoğlu A., Çakmak H.B., Şen B., Delen D., Supporting the diagnosis process and processes after treatment by using image segmentation and image simulation techniques: Keratoconus example, Journal of the Faculty of Engineering and Architecture of Gazi University, 31 (3), 737-747, 2016.

13. Reilly J.P., Maximum pulsed electromagnetic field limits based on peripheral nerve stimulation: application to IEEE/ANSI C95.1 electromagnetic field standards, IEEE Transactions on Biomedical Engineering, 45 (1), 137-141, 1998.

14. Bottomley P.A., Edelstein W.A., Power deposition in whole-body NMR imaging, Medical Physics, 8 (4), 510-512, 1981.

15. Saritas E.U., Goodwill P.W., Zhang G.Z., Conolly, S.M., Magnetostimulation limits in magnetic particle imaging, IEEE Transactions on Medical Imaging, 32 (9), 1600-1610, 2013.

16. Saritas E.U., Goodwill P.W., Conolly S.M., Effects of pulse duration on magnetostimulation thresholds, Medical Physics, 42 (6), 3005-3012, 2015.

17. Demirel O.B., Saritas E.U., Effects of Duty Cycle on Magnetostimulation Thresholds in MPI, International Journal on Magnetic Particle Imaging, 3 (1), 1703010, 2017.

18. Goodwill P.W., Conolly S.M., The X-space formulation of the magnetic particle imaging process: 1-D signal, resolution, band width, SNR, SAR and magnetostimulation, IEEE Transactions on Medical Imaging, 29 (11), 1851-1859, 2010.

19. Goodwill P.W., Conolly S.M., Multidimensional XSpace Magnetic Particle Imaging, IEEE Transactions on Medical Imaging, 30 (9), 1581-1590, 2011.

20. Konkle J.J., Goodwill P.W., Saritas E.U., Zheng B., Lu K., Conolly S.M., Twenty-fold acceleration of 3D projection reconstruction MPI, Biomed Tech (Berl), 58 (6), 565-576, 2013.

21. Demirel O.B., Sarica D., Saritas E.U., Rapid Scanning in X-Space MPI: Impacts on Image Quality, International Workshop on Magnetic Particle Imaging, Lübeck-Almanya, 16-18 Mart 2016.

22. Ferguson R.M., Khandhar A.P., Kemp S.J., Arami H., Saritas E.U., Croft L.R., Konkle J., Goodwill P.W., 
Halkola A., Rahmer J., Borgert J., Conolly S.M., Krishnan K.M., Magnetic Particle Imaging with Tailored Iron Oxide Nanoparticle Tracers, IEEE Transactions on Medical Imaging, 34 (5), 1077-1084, 2015.

23. Croft L.R., Goodwill P.W., Conolly S.M., Relaxation in X-Space Magnetic Particle Imaging, IEEE Transactions on Medical Imaging, 31 (12), 2335-2342, 2012.
24. Croft L.R., Goodwill P.W., Konkle J.J., Arami H., Price D.A., Li A.X., Saritas E.U., Conolly S.M., Low drive field amplitude for improved image resolution in magnetic particle imaging, Medical Physics, 43 (1), 424-435, 2016.

25. Wang Z., Bovik A.C., Sheikh H.R., Simoncelli E.P., Image Quality Assessment: From Error Visibility to Structural Similarity, IEEE Transactions on Image Processing, 13 (4), 600-612, 2004. 
